Georgia State University

ScholarWorks @ Georgia State University

$4-2-2008$

\title{
The Relationship Between Suicidal Behavior and Productive Activities of Young Adults
}

\author{
Erdal Tekin \\ Georgia State University, tekin@gsu.edu \\ Sara Markowitz \\ Emory University, smarkow@rutgers.edu
}

Follow this and additional works at: https://scholarworks.gsu.edu/uwrg_workingpapers

\section{Recommended Citation}

Tekin, Erdal and Markowitz, Sara, "The Relationship Between Suicidal Behavior and Productive Activities of Young Adults" (2008). UWRG Working Papers. 15.

https://scholarworks.gsu.edu/uwrg_workingpapers/15

This Article is brought to you for free and open access by the Usery Workplace Research Group at ScholarWorks @ Georgia State University. It has been accepted for inclusion in UWRG Working Papers by an authorized administrator of ScholarWorks @ Georgia State University. For more information, please contact scholarworks@gsu.edu. 
Working Paper 2008-4-2

April 2008

The Relationship Between

Suicidal Behavior and Productive

Activities of Young Adults

Erdal Tekin

Georgia State University

Sara Markowitz

Emory University

This paper can be downloaded at: http://aysps.gsu.edu/uwrg-research.html

GeorgaState

ANDREW YOUNG SchOOL

University。 
The Relationship between Suicidal Behavior and Productive Activities of Young Adults

Erdal Tekin (corresponding Author)

Sara Markowitz

Running head: Suicidal Behavior and Productive Activities

Erdal Tekin

Department of Economics, Georgia State University, NBER, and IZA

Department of Economics, Andrew Young School of Policy Studies

P.O. Box 3992

Atlanta, GA USA 30302-3992

Email: tekin@gsu.edu

Phone: (404) 413-0163

Sara Markowitz

Department of Economics, Emory University and NBER

Department of Economics, Emory University

Atlanta, GA 30322-224

Email: smarkow@ rutgers.edu

Phone: (404) 727-7370

Keywords: Suicide, Employment, Schooling

JEL Classification: I1, J2, J3

We would like to express our sincere thanks to Carol Tremblay for her very helpful suggestions and comments. Jason Delaney and Solomon Tesfu provided excellent research assistance. 
The Relationship between Suicidal Behavior and Productive Activities of Young Adults

\begin{abstract}
This paper provides an analysis of the link between suicidal behaviors and human capital formation of young adults in the United States. Using data from the National Longitudinal Study of Adolescent Health, we estimate the effects of suicide thoughts and attempts on the probability of engaging in work or attending school. The richness of the data set allows us to implement several strategies to control for unobserved heterogeneity and the potential reverse causality. These include using a large set of control variables that are likely to be correlated with both suicidal behavior and the outcome measures, an instrumental variables method, and fixed effects analyses from the subsamples of twin and sibling pairs. Results from the different identification strategies consistently indicate that both suicide thoughts and suicide attempts decrease the likelihood a young adult individual engages in work or schooling.
\end{abstract}




\section{Introduction}

Suicides among youths have reached an alarming rate in recent years and are now the third leading cause of death for those aged 15-24 (Anderson and Smith 2003). Since 1950, the suicide rate has tripled among youths (Cutler et al. 2001). Even more striking is the number of suicide attempts by young individuals. For every teen that commits suicide, as many as 150 teens attempt suicide (Chatterji et al. 2004). Concern over the health and well-being of youths has prompted the U.S. Department of Health and Human Services (DHHS) to develop a national strategy for suicide prevention. This comprehensive campaign includes developing public education campaigns, increasing the number of suicide prevention programs in schools, work sites and community services, and incorporating screening at primary health care facilities.

Suicide attempts, regardless of whether or not they are completed, impose real health care and other costs on individuals and society. For example, the direct medical costs associated with both completed and medically treated suicides by youths under 21 amounted to $\$ 945$ million in 1996, and lost future earnings are estimated at \$2.85 billion (Miller et al. 1999). A suicide attempt can have adverse effects on one's current and future labor market productivity due to a bodily injury or permanent disability, lost credibility in the workplace, interruptions at work and school, lost interest in future employment efforts, and continuing psychological problems. Despite this strong link between suicidal behavior and labor market outcomes, our knowledge of the potential effects of suicidal behavior on labor market and school outcomes is very limited. This relationship is also confounded by the potential effects that poor school or labor market outcomes have in contributing to suicidal behaviors.

This paper explores in depth the link between suicidal behaviors and engaging in productive activities. Specifically, we focus on labor market and educational outcomes of young adults who are at a stage in life characterized by intense investment in human capital. These adults are in school, 
participating in job training or are just starting their careers. Disruptions to these investments can have profound, long-term implications for future earnings and occupational choices. If there is a positive link between the quality of the initial job and future labor market success, the answer to this question will provide important insights into the long-term effects of suicidal behavior and will help structure a better-informed policy debate over the effectiveness of cognitive behavioral therapies and anti-suicide programs such as those implemented at high schools in the United States.

A study by the Centers for Disease Control and Prevention (1992) documents that most antisuicide programs focus on teenagers with little emphasis given to suicide among young adults. This is partly due to the fact that teenagers in high school are easier to reach than young adults and partly due to a failure to appreciate that the suicide rate is generally twice as high among persons 20-24 years of age as among adolescents 15-19 years of age. The study recommends an expansion of the suicide prevention efforts for young adults 20-24 years of age.

The paper is organized as follows. Section 2 provides a summary of the previous evidence on the subject. Section 3 discusses the econometric methodology. Section 4 introduces the data set and the variables used in the analyses. Section 5 summarizes the results. Section 6 concludes the paper.

\section{Background}

Researchers believe that almost all individuals who commit suicide have a diagnosable mental disorder, and mental illnesses are also primary risk factors for suicide thoughts and attempts (Maris et al. 1992, Alexopoulos et al. 1999, Johnson et al. 1990). It has been estimated that twothirds of people who commit suicide have a depressive illness; 5 percent suffer from schizophrenia; and 10 percent meet the criteria for other mental illnesses including borderline personality disorder. The relationship between mental illness and suicidal behaviors also holds for youth (Fergusson and 
Woodward 2002). One estimate shows that over 90 percent of children and adolescents who commit suicide have a mental disorder (Shaffer and Craft 1999).

While depressive illnesses are most commonly associated with suicidal behaviors, other disorders are also frequently observed, including substance abuse disorders, attention deficit disorder, anxiety disorders, panic disorder, schizophrenic disorders, post-traumatic stress disorders, borderline personality disorders (Alexopoulos et al. 1999, Johnson et al. 1990, Goldsmith et al. 2002). For example, in a study of youth in a psychiatric hospital, Borst and Noam (1989) find that conduct disorders are the most prevalent type of disorders diagnosed among suicide attempters. The authors conclude, "factors such as impulsivity and anger may contribute significantly to suicidal behavior in children and adolescents." (p. 174) Personality disorders are also highly prevalent, with a diagnosis rate of 40 to 53 percent among youth who have committed suicide (Goldsmith et al. 2002).

It is important to note that the mental illnesses that manifest themselves through suicidal behaviors likely represent the most severe cases of illness. Simon and Von Korff (1998) find that among insured patients receiving treatment for depression, the highest risk of suicide was among those receiving inpatient treatment and medication and the lowest risk was found among individuals receiving outpatient treatment without medication.

Cutler et al. (2001) argue that there is a fundamental difference between suicide attempts and completions among youth, where the latter is a result of the desire to die and the former is not. The authors discuss four reasons for suicide attempts among youth: The first involves strategic motives to "... signal others that they are unhappy or to punish others for their unhappiness." (p. 233). The second is the depression theory where youths cross some unhappiness threshold and desire to take their own lives. The third is the contagion theory where a "social multiplier' may amplify the effects of stressors leading to depression or may amplify the effects of factors leading to 
suicidal signaling as a method of conflict resolution among youths." (p. 233-234). The fourth theory involves the combination of unhappiness and the means to kill themselves. Even in the absence of the intent to die, it is clear that underlying mental states are extremely important in the theories predicting suicidal behaviors.

In contrast to the conclusions drawn by Culter et al., Boergers et al. (1998) find that most adolescents who attempt suicides cite the reasons of wanting to die or to get relief from a terrible state of mind as the primary reason for the attempt. Few identify the attempt as a cry for help or a way of getting back at someone. Although it is difficult to pinpoint the exact underlying motives for a suicide thought or attempt, the link between suicide and mental illness cannot be denied.

In this paper, we focus on suicidal behaviors such as suicidal thoughts and attempts rather than depression or any other specific mental illness. Based on the literature described above, we argue that suicide ideation and attempts are most likely manifestations of severe mental illnesses. However, we also allow for the possibility that, in youth, these behaviors may be methods of signaling or punishing others, or of conflict resolution. We believe that given the vast number of different mental illnesses and related stressors that are believed to contribute to suicide behaviors, estimating models of one or two specific illnesses is unlikely to draw a complete and informative picture of the effects of mental well-being on productive activities.

Regardless of the underlying causes, suicide thoughts and attempts may have negative consequences for school and labor market outcomes through multiple channels and are therefore important to study. For example, injuries from failed suicide attempts may contribute to absenteeism and reduced productivity at work and school. About 116,000 individuals who survive a suicide attempt are hospitalized with an average hospital stay of ten days and an average cost of $\$ 15,000$ (Miller 1995). Seventeen percent of these people are permanently disabled and restricted in their ability to work (Miller 1995). Suicidal behavior may also result in lower engagement in work 
and schooling activities due to reduced concentration and cognitive abilities (Greenberg et al. 1990, Conti and Burton 1994). These functional limitations may also contribute to worsened labor market and school outcomes. Furthermore, the underlying mental illnesses and life stressors that we observe through suicidal behaviors may also contribute to outcomes such as teenage pregnancy and marital instability, which may then result in low educational attainment, poor labor market productivity and lower wages (Kessler et al. 1997, Overbeek et al. 2003).

There is evidence that individuals with mental illnesses and those who exhibit suicidal behaviors are less likely to reach their potential academically. According to the Department of Education, 50 percent of children with serious emotional and behavioral problems drop out of high school, compared to 30 percent of students with other disabilities (U.S. Department of Education 2001). Stoep et al. (2003) find that over half of the adolescents in the United States who fail to complete their secondary education have a diagnosable psychiatric disorder. Using a twin sample from Minnesota, Marmorstein and Iacono (2001) conclude that depression is related to significant difficulties in functioning and school adjustment which result in an increased number of suspensions and failure of classes. Slap et al. (2001) document that those who attempt suicide perform poorer at school and have a lower level of school connectedness than non-attempters. In sum, suicidal behaviors can affect an individual's productivity and academic achievement, which may have implications for future outcomes. The mechanisms may be direct, for example, when injuries and reduced concentration result from suicide thoughts or attempts; or indirect, when the outcomes associated with underlying factors negatively influence productivity and academic success.

The relationship from labor market outcomes to poor mental health also cannot be ignored. Mental health may certainly be affected by labor market involvement as higher wages may improve mental health. In the simplest case, more income can allow a person to purchase treatment for 
mental illness. Higher incomes might also remove stress from financial insecurity and contribute to good health. Hamermesh and Soss (1974) propose that suicide occurs when an individual's taste for living plus the total discounted lifetime utility, which is a function of permanent income, equals zero. Aggregate suicide rates should therefore fluctuate with expectations about future income and the unemployment rate. Indeed, a number of studies on the economic determinants of suicide show that suicide rates fall with rising incomes and rise with the unemployment rate (see Marcotte 2003 for a review). In short, mental health status and labor market outcomes may be intertwined. In this case it is necessary to model the link between suicidal behavior and labor market outcomes as simultaneous equations in order to obtain unbiased estimates.

\section{Previous Research}

To the best of our knowledge, only one previous study, Marcotte (2003), has directly estimated the effects of suicide thoughts and attempts on labor market outcomes. The lack of economic studies on suicidal behavior is largely due to lack of individual level data. The majority of studies on the topic use aggregate data from sources such as vital statistics to look at the correlations between economic outcomes such as income and suicidal behavior. However, to the extent that the underlying behavioral mechanism that leads to suicide decisions and thoughts is based on microlevel utility maximization decisions, aggregate data analysis is unsatisfying (Marcotte 2003). Using data from the National Comorbidity Survey conducted in 1991-1992, Marcotte (2003) finds that suicidal behaviors are associated with lower current income, although suicide attempters are associated with a higher current income than those who only thought about suicide. The higher income may result because of income transfers from family members or the government following the attempt. Subsequent mental health treatment may also improve mental health and labor market outcomes. The sample size in this paper is 5,877 and the target population is all adults between ages 
18-54. In contrast, we use a much larger sample in this study from a more recent survey and we explicitly look at the responses of young adult population between ages 18 and 26. Our outcome measures differ in that we examine school and work activities. Finally, the cross-sectional nature of the data set used in Marcotte study and the lack of any potential instruments do not allow the author to rule out the possibility that his findings are due to heterogeneity (Marcotte 2003, p. 640).

Despite the lack of evidence in the literature of the labor market effects of suicidal behaviors, a number of studies have examined the relationship between mental illness and labor market outcomes. Given the close link between suicide and mental illness, this literature can provide insights into the true nature of the relationship. Most of this research shows that poor mental health is associated with reduced success in the labor market among adults. The first generation of papers focusing on the effects of mental health status on labor market outcomes acknowledges but ignores the potential endogeneity between the outcomes. Studies such as Bartel and Taubman (1979, 1986), Mullahy and Sindelar (1990), and Frank and Gertler (1991) all show that individuals with reported or diagnosed mental disorders have worse labor market outcomes than other individuals. Bartel and Taubman $(1979,1986)$ find that earnings are lower among individuals with a recent or past mental illness diagnosis. Mullahy and Sindelar (1990) find that people with both self-reported and diagnosed mental illnesses are associated with a lower probability of working. Frank and Gertler (1991) show that having a mental illness reduces one's earnings. This paper is also important because it shows the bias introduced by using a utilization based measure that disregards mental health status rather than population based measure of mental illness. The bias arises because only a subset of the mentally ill seeks treatment.

The second generation of papers explicitly tests for and if necessary, accounts for, the potential endogeneity of mental illness in the equations for labor market outcomes. The results of these studies are generally consistent with the first generation studies and find worse labor market 
outcomes among mentally ill individuals. For example, Ettner et al. (1997) use the National Comorbidity Survey to study effects of the presence of specific mental illnesses (such as schizophrenia and major depression) on the probability of being employed, usual hours of work and annual income. The number of psychiatric disorders experienced during childhood and parental history of mental illness serve as instrumental variables. Results show that psychiatric disorders have detrimental effects on all three labor market outcomes. French and Zarkin (1998) examine the relationship between symptoms of emotional and psychological problems and earnings at a large worksite in the U.S. Results of tests for the endogeneity of mental health in the earnings equation leads the authors to treat mental health as exogenous. They find that earnings are lower and absenteeism is higher among those reporting mental health problems. Hamilton et al. (1997) examine the simultaneous relationship between unemployment and mental health. Using maximum likelihood estimation, the authors find evidence that being employed is associated with improved mental health and that being in poor mental health is associated with a lower probability of employment.

Our paper expands the second generation literature by looking at the effects of suicide thoughts and attempts on the probability of engaging in a productive activity, that is, work or school. Whereas the average age in many of the above mentioned studies ranges from 35 to 40 , this is the first paper to examine schooling and labor market outcomes for a sample of young adults. This paper also uses a variety of methods to control for the potential endogeneity of suicidal behaviors, which allows us to asses the validity of our conclusions. Suicide thoughts and attempts are advantageous in that we are able to identify people in severe mental distress and are not limited to drawing conclusions for one particular mental illness, such as depression or schizophrenia. Another advantage is that these measures of mental health are population based rather than 
treatment based, the latter of which, as Frank and Gertler (1991) point out, can produce biased results.

\section{Methods}

The goal of this paper is to model the effect of suicidal behavior on schooling and labor market outcomes. Therefore, the basic econometric model can be expressed as:

$$
\mathrm{L}_{\mathrm{i}}=\beta \mathrm{S}_{\mathrm{i}}+\mathrm{X}_{\mathrm{i}} \alpha+\gamma_{\mathrm{s}}+\delta_{\mathrm{h}}+\varepsilon_{\mathrm{i}}
$$

where $\mathrm{L}_{\mathrm{i}}$ is a dichotomous indicator for whether the individual $\mathrm{i}$ is either at work or school or both, and is 0 otherwise. $S_{i}$ is a measure of suicidal behavior and $X_{i}$ is a vector of personal and family characteristics. The $\gamma_{\mathrm{s}}$ and the $\delta_{\mathrm{h}}$ are vectors of state and school fixed effects, respectively.

Estimating unbiased effects of suicidal behaviors on labor market outcomes is a difficult task. Biased estimates can come from two sources of endogeneity. The first, statistical endogeneity, results from unobserved factors in the error term of equation 1 that are correlated with both the schooling/labor market outcome and the suicidal behaviors. For example, a lack of a caring home environment might lead to insufficient investment in activities of child development and nutrition. This in turn could result simultaneously in poor labor market and schooling outcomes and poor mental health status. Estimates of the impact of suicidal behavior that do not take account of this type of effect would be biased. The second source of endogeneity, structural endogeneity, comes from the potential reverse causality from labor market and schooling outcomes to mental illness and suicidal tendencies. For example, unemployment and poor school performance may contribute to stress and poor mental health outcomes. Not accounting for this relationship would bias the estimates of the suicidal behaviors in equation 1. In addition to the potential endogeneity of suicidal behavior measures, these measures may contain measurement error since they are self-reported, 
despite additional steps taken to ensure confidentiality. Therefore, measurement error is another potential source for bias in the estimated effect of suicidal behavior on our outcome measures.

We address the potential endogeneity problems in a number of ways. First, we will control for the statistical endogeneity by utilizing a full set of variables designed to minimize or eliminate the unobserved factors left in the error term. We also include vectors of fixed effects for the individual's state of residence in Wave 3 and school attended in Wave 1 . The school fixed effects will control for any school level experiences and environmental/neighborhood characteristics that may be correlated with both the future productivity of the individuals and their mental health such as their suicidal tendencies. For example, there may be a higher incidence of suicide attempts in one school for one reason or another. The higher exposure of students to suicide events in these schools would likely affect their suicidal tendencies as well as their school and possibly labor market performance. Also school fixed effects will capture any neighborhood and school characteristics such as poverty and school violence which could be correlated with both suicidal behavior and productive activities. The state fixed effects are included in the model to control for the unobservables that might be correlated with both depression/suicide and labor market outcomes such as unattractive economic conditions in the state.

In addition to the fixed effects, we include in our models a rich set of variables designed to account for the home and family environment. By comparing models with and without these background variables, we will be able to see the extent to which correlation between suicidal behavior and the outcome variable is affected by these control variables. We are also able to control for suicidal behaviors of the respondents and their family members from Wave 1, when these individuals were at high school. These will further help us eliminate the unobserved heterogeneity. ${ }^{1}$

\footnotetext{
${ }^{1}$ Selection bias may be present in our data as it is possible that individuals with severe mental illness in Wave 1 may have dropped out of the sample because of hospitalization or having committed suicide (although only 96 individuals are dropped from the data between Waves 1 and 3 due to death, the cause of which is unknown). If this is the case then
} 
Lastly, we include measures of current and previously observed depressive symptoms to account for one of the many mental illnesses that may confound the relationship between human capital and suicidal behaviors. These measures are all discussed in further detail below.

In order to guard against any bias from potential measurement error and endogeneity, we will next turn to the instrumental variables (IV) method. The IV method can be used to address both forms of endogeneity discussed above. The IV method will yield unbiased estimates of the effects of suicidal behaviors if instruments can be found which 1) are correlated with suicidal behaviors; and 2) are not correlated with the outcomes except through their effects on the probability that an individual is suicidal. Variables describing the suicidal behaviors of friends from Wave 1 and Wave 3 will be used as instruments for identification under the assumption that these variables will predict an individual's own decision on suicide while having no direct impact on his/her work and school decisions.

One potential concern with the instrumental variables is that if individuals with suicidal tendencies associate with other people who are suicidal themselves, then the IV strategy would not work. As we will show below, this does not appear to be a problem and suicidal behavior of friends appears to be a valid instrument. Using lagged suicidal behavior of friends might be an alternative way to address some of these concerns but the lagged value does not have much predictive power in the first stage suicide models. We rely on friends' suicidal behaviors as instruments in the absence of better alternatives.

The third way we address the endogeneity issue and guard against unobserved omitted family and background characteristics is to exploit the genetic oversample of the data and estimate sibling and twin fixed effect models. Any observed or unobserved background measures common to both siblings and especially twins will be controlled by estimating a model with family fixed

our sample would represent people with less severe illnesses. The extent of the problem should be very small as only 41 of the original 20,745 adolescents were not re-interviewed because they were physically or mentally incapable. 
effects. To the extent that sibling or twin pairs are exposed to the same unobservables, a family fixed-effects model will further eliminate unobserved heterogeneity. In order to implement this design, we restrict our sample to pairs, and estimate models of the form:

$$
\mathrm{L}_{\mathrm{i}}=\delta \mathrm{S}_{\mathrm{i}}+\mathrm{X}^{\prime}{ }_{\mathrm{i}} \lambda+\gamma_{\mathrm{s}}+\delta_{\mathrm{h}}+\gamma \text { PairlD }_{\mathrm{f}}+\eta_{\mathrm{i}},
$$

where $\mathrm{X}^{\prime}$ is a vector of fewer control variables then specified in equation 1 , and PairlD $_{\mathrm{f}}$ is a vector of family identifiers. Since any observed or unobserved background measures common to both siblings will be controlled for by the fixed effects, only things that differ between siblings, such as gender, marital status, test scores, and drug use will be included in the vector $\mathrm{X}^{\prime}$. These fixed effects models are powerful ways to control for family background characteristics and experiences common to both individuals that might be correlated with the suicidal behaviors and the outcome measures.

Twin and sibling fixed effects models also provide a way to assess the importance of measurement error in the suicidal behavior variables (Currie and Stabile 2007). If one can argue that suicidal behavior is likely to be similar between twins and siblings then the within family differences in suicidal behavior must be a more noisy measure than between family differences. Then we would expect an increased attenuation bias in the fixed effects estimates than the OLS estimates (Currie and Stabile 2007). As we present evidence in the results section, we believe that this is unlikely to be the case.

Unfortunately, one potential problem with this fixed effects approach is that the results may be biased if there are individual experiences that are correlated with suicidal behavior and that differ between siblings/twins. Given that our sample is of young adults, it is likely that events and environments related to the family will be picked up by the fixed effects. Also, it is important to acknowledge the possibility that an individual may be depressed or traumatized by the suicidal behavior of his or her sibling or twin, which may in turn cause him or her to engage in suicidal 
thoughts or attempts. In this case, the difference in labor market outcomes between the two will be reduced, which may cause bias in the estimated coefficients. However, we guard against this problem by controlling for depression in Waves 1 and 3 in some of our specifications.

\section{Data}

The data for this project come from the National Longitudinal Study of Adolescent Health (Add Health). ${ }^{2}$ The Add Health is the largest and most comprehensive nationally representative survey of adolescents ever undertaken. The first wave of the survey was administered between September 1994 and April 1995 to 20,745 youths in grades 7 through 12. Approximately 200 adolescents were randomly selected from each of 132 schools that are representative of U.S. schools with respect to county, urbanicity, school size, school type, and ethnicity. The adolescents were interviewed for the second time between April and August 1996 for Wave 2. The interviews were administered using a CAPI/CASI survey instrument.

Of the original Wave 1 respondents, 15,170 were re-interviewed between August 2001 and April 2002 for Wave 3. There are about 5,500 cases excluded from Wave 3 for various reasons including moving out of country, active military duty, incarceration and being institutionalized, death, and failure to locate in repeated attempts. In order to assess whether individuals who are suicidal in Wave 1 are more likely to be excluded from Wave 3, we compared the means of suicide thoughts and suicide attempts as reported in Wave between those who exit the sample from Waves 1 to 3 and those who stayed in the sample. For both suicide thoughts and suicide attempt, we could not reject the hypothesis that these means are equal to each other. Therefore, we believe that the

\footnotetext{
${ }^{2}$ The Add Health is a program project designed by J. Richard Udry, Peter S. Bearman, and Kathleen Mullan Harris, and funded by a grant P01-HD31921 from the National Institute of Child Health and Human Development, with cooperative funding from 17 other agencies. Special acknowledgment is due Ronald R. Rindfuss and Barbara Entwisle for assistance in the original design. Persons interested in obtaining data files from Add Health should contact Add Health, Carolina Population Center, 123 W. Franklin Street, Chapel Hill, NC 27516-2524 (www.cpc.unc.edu/addhealth/contract.html).
} 
sample attrition is unlikely to be correlated with the suicidal behaviors in our data. The Wave 3 respondents constitute our main analysis sample. As described below, we also utilize a number of questions from Wave $1 .^{3}$

One interesting feature of Add Health is the genetic oversample, which consists of a large number of siblings and twins. As one of our identification strategies, we limit our sample and estimate fixed effect models. There are a total of 2,134 siblings and 760 twins in the sample. It is noteworthy that the fractions of siblings and twins who report suicide thoughts and suicide attempts are similar to that reported in the full sample.

\section{Dependent Variables}

Our dependent variable is a dichotomous indicator for whether or not the individual is currently engaged in a productive (or work-related) activity. This indicates whether the individual currently works, attends school, or both. That is, the variable Work-School equals 1 if the respondent is either working, in school, or both, and equals 0 otherwise. We focus on both outcomes because the age range of our sample, 18-26, represents the ages where individuals are commonly engaged in both activities. In fact, about 38 percent reported going to school, and 63 percent of those who are working are also at school which makes it difficult to separate these two outcomes. $^{4}$

\section{Suicide Variables}

\footnotetext{
${ }^{3}$ We exclude responses from Wave 2 because a large number of individuals were not interviewed in Wave 2 but are interviewed Waves 1 and 3 .

${ }^{4}$ Another possible outcome to analyze is the wage rate. However, many of these students are employed at or near minimum wage (nearly forty percent making less than seven dollars per hour) and the job choices in school and the associated wages may not reflect accurately what will be their wage trajectory in the future.
} 
The Add Health contains a series of questions about suicidal behaviors of the respondents, their friends, and family members in each wave. The self-suicidal behavior questions include whether the respondent seriously thought about committing suicide in the past 12 months (termed suicide thoughts) and whether she/he attempted suicide in the past 12 months (termed suicide attempt). To maintain confidentiality, no paper questionnaires were used in Add Health. Rather, data were recorded on laptop computers. For more sensitive material such as suicidal behavior, the respondent entered his or her own answers in privacy. ${ }^{5}$ The two questions on suicide from Wave 3 constitute our primary measures of suicidal behavior. To the extent that suicide attempts are reflective of a more serious mental health problem than having just suicide thoughts, these two measures provide an opportunity to assess the differential effect of the degree of suicidal behavior on our outcome measures.

Table 1 presents the descriptive statistics of the variables used in the analyses as well as their definitions. The first column displays the means for the full sample. The next two columns display the means for the sub-sample of individuals who report that they had suicide thoughts in the past 12 months and those who do not report having such thoughts. As shown in Table 1, 6 percent of the sample seriously thought about committing suicide during the past 12 months and 1.6 percent reported attempting suicide during the past 12 months. The same figures from Wave 1 are 13.4 percent and 3.7 percent, respectively. Note that among individuals with suicide thoughts, about 27 percent actually attempted suicide. These statistics correspond well with figures from other surveys. For example, the rates of suicide thoughts and attempts from the 1991-1992 National Comorbidity Survey are 5.2 percent and 1.4 percent, respectively, for youths ages 15-24.

In Wave 3, 6.7 percent of our sample reported having friends who tried to kill themselves during the past 12 months, and about 3 percent reported having family members who tried to kill

\footnotetext{
${ }^{5}$ For less sensitive material, the interviewer read the questions and entered the respondent's answers
} 
themselves during the same period. These numbers are down from 17.5 percent for friends and from 4.4 percent for family members in Wave 1 . The decline in the suicidal behavior of family members between Wave 1 and Wave 3 is consistent with the general decline in suicides that started in 1992 (Lubell et al. 2004).

As illustrated in Table 1, 83.4 percent of our sample is engaged in a work or schooling activity. The engagement in productive activity is less common (79.2 percent versus 83.7 percent) among those with suicide thoughts than those with none.

\section{Other Control Variables}

The richness of the Add Health allows us to control for a large set of background variables in our analyses. Their definitions and descriptive statistics are reported in Table 1. The set includes indicators for age, gender, race, ethnicity, U.S. resident status, marital status, mother's educational attainment, non-wage income, religion, physical health status, and standard Picture Peabody Vocabulary Test scores from Wave $1 .{ }^{6}$ We also explore expanded models with additional covariates. Three groups of variables are included — background family characteristics, background individual characteristics, and history of substance use. The variables in each are described below.

Background family characteristics include indicators of whether the person experienced any type of abuse during childhood, whether she/he spent time in foster care, and whether the father had ever been in jail. The background individual characteristics include indicators for whether the respondent exhibits the following behaviors or attitudes: volunteer work as a teenager; ran away from home when in high school; had psychological or emotional counseling in Wave 1; repeated a grade as of Wave 1; was suspended from school in Wave 1; had trouble with teachers everyday in

\footnotetext{
${ }^{6}$ The Add Health Picture Vocabulary Test (AHPVT) is a computerized, abridged version of the Peabody Picture Vocabulary Test-Revised (PPVT-R). The AHPVT is a test of hearing vocabulary, designed for persons aged $21 / 2$ to 40 years old who can see and hear reasonably well and who understand standard English to some degree.
} 
Wave 1; had trouble with students everyday in Wave 1; felt close to people at school in Wave 1; felt part of school in Wave 1; and felt that students were prejudiced in Wave 1. Measures of past substance use include the following dichotomous indicators: cocaine use in Wave 1; marijuana use in Wave 1, participation in drug abuse program in Wave 1; being drunk at least once a week past 12 months in Wave 1; reports of alcohol being easily available at home in Wave 1; and reports of drugs being easily available at home in Wave 1.

It is important to include the extensive sets of variables because they will help reduce the amount of unobserved factors in the error term that are correlated with both suicidal behavior and productive activity. For example, negative experiences early in life could predispose individuals to risky, self-destructive or aggressive behaviors by impairing their self-esteem and damaging their ability to form relationships with others (Veltman and Browne 2001, Felitti 1998, and Dube et al. 2003). However, many of these variables may be endogenous themselves, therefore models are estimated with and without these potentially endogenous variables so that we can gauge the effects of the inclusion or exclusion of these variables on the coefficients of interest.

As part of the expanded set of variables, we also include in some models measures of mental health problems and depressive symptoms. Depressive symptoms are measured in Wave 1 of Add Health using 18 of the 20 standard questions from the Center for Epidemiological Scale for Depression (CES-D). ${ }^{7}$ In Wave 3, Add Health includes only 9 of these questions. Responses in the depressive symptoms scale include 0 (never or rarely), 1 (sometimes), 2 (a lot of the time), and 3 (most of the time or all of the time). ${ }^{8}$ After summing up scores from these questions, we generate dichotomous indicators that equals 1 if the individual's score places them at the $80^{\text {th }}$ percentile or higher in the sample distribution for that wave and 0 otherwise. The $80^{\text {th }}$ percentile corresponds to

\footnotetext{
${ }^{7}$ See Radloff (1977) for more on the CES-D scale.

${ }^{8}$ Several items assess positive symptoms. These are reversed before the scale scores were calculated. The Add Health CES-D is shown to have a high internal consistency (Goodman 1999).
} 
the frequently used CES-D score cut-off of 16 or more to indicate depression (Civic and Holt 2000). ${ }^{9}$ We consider these indicators as reflecting elevated levels of depressive symptoms. The CES-D scale does not correspond to a DSM-IV diagnosis of major depression. It is used primarily as a screening tool for depression, not as a diagnostic tool (Eaton et al. 2003). We recognize that depression is endogenous in our models for the same reasons that suicidal behaviors are endogenous. For this reason we present models with and without the measures of depression. In addition, we present some models that only include the depression measure from Wave 1 in order to avoid some of the bias due to potential reverse causality, as depression will have been measured before the labor market and schooling choices are observed. Lastly, we show models that include depression measured both at Wave 1 and Wave 3 .

Note that the effects of depressive symptoms on labor market and school outcomes are not the main focus of this paper because the CES-D is primarily a screening tool for depression and may not be able to identify cases of depression precisely. Also, the scale of depressive symptoms is a very narrow measure of mental illness as depression is only one of the many factors that affect human capital formation. Suicide behaviors, by contract, are associated with many different mental illnesses and therefore represent a broad scope of illnesses. Suicidal behaviors are much more likely than the CES-D score to represent the most severe cases of illness. It is the severe cases that are the most likely to have negative schooling and labor market outcomes.

Despite the problems with the depression measures, we believe it is important to show models that include and exclude these measures in order to see the influence of this mental illness on the estimates of suicidal behaviors. This exercise will help us to gauge, albeit rather imperfectly, whether or not suicidal behaviors are merely representing the underlying depressive symptoms. Large decreases in the magnitude of the coefficients on suicide thoughts and attempts that result

\footnotetext{
${ }^{9}$ Using a continuous CES-D scale yields very similar results to those presented below.
} 
when our measures of depression are included will indicate that the suicidal behaviors are likely representing the effects of this one particular mental illness which is commonly associated with suicide. Small or no changes in the coefficients will imply that suicidal behaviors affect human capital formation independent of depressive symptoms, however, we still will not be able to isolate indirect effects from other mental illness. That is, even with depression held constant, the coefficients on suicidal behaviors will still represent a combination of the direct and indirect effects since depression is only one of the many conditions associated with suicides. Unfortunately data limitations do not allow us to control for all of the possible comorbid conditions.

In order to conserve a sample as large and representative as possible, we constructed a dummy variable for "missing category" for the variables for which at least one observation was missing due to any reason. This method allows us to utilize a sample size of 14,401 , which is larger than those usually employed in most other studies. Age in our sample only ranges from 18 to 26 . We use dummy variables for age in order to capture any non-linear association between age and the outcomes variables. Certain variables from Wave 1 are used to avoid the potential bias from any reverse causality. For example, we use the standard test scores and alcohol and illicit drug use from Wave 1 because the current values may be endogenous to the current productive activity. Furthermore, we do not include the individual's own years of schooling into the models because (1) this variable may be endogenous; and (2) 38 percent of our sample is still in school. Instead, we adopt a quasi-reduced form approach by substituting in the determinants of human capital accumulation, such as mother's education, physical health, and non-wage income. ${ }^{10}$ However, we experimented with models that include the number of years of schooling, models that include the standard test scores from Wave 3, and models that are only estimated for the non-school sample (the

\footnotetext{
${ }^{10}$ Our health variable is a measure of physical health. Therefore it should not be co-linear with the suicidal behavior. In any case, we estimated models excluding physical health as a control and the results remained the same.
} 
outcome is "work" in that case). Results are all similar to those presented in this paper and are available upon request.

The large sample size, the longitudinal nature of the data, along with the genetic oversample, and the richness of the available individual and family characteristics make the Add Health an excellent data set for examining the link between suicidal behaviors, underlying mental health issues and productive activities. We believe that until other longitudinal labor market surveys include comprehensive measures of mental illness, the Add Health is probably the best available data set to address the question studied in this paper.

\section{Results}

We begin by presenting OLS results for the effects of suicide thoughts and attempts on the probability of engaging in a productive activity as measured by working or attending school. Linear probability models are shown with robust standard errors to adjust for heteroskedasticity in the error term. ${ }^{11}$ Tables $2 \mathrm{~A}$ and $2 \mathrm{~B}$ display the results for the effects of suicide thoughts and attempts, respectively. The columns in these tables present increasingly rich specifications. All of these specifications contain both the state and school fixed effects. Column 1 shows the baseline estimates from a specification that includes variables representing only the individual's own characteristics. Column 2 adds to this list six variables on past own and family suicide attempts along with three variables representing family environment. Column 3 expands the variables in column 2 by adding depression and counseling variables from Wave 1 and column 4 add to this set the depression indicator from Wave 3. Lastly, column 5 includes additional family background and individual attitude characteristics from Wave 1. These variables may be endogenous, but as we will

\footnotetext{
${ }^{11}$ We specify linear equations for ease of estimation and interpretation. Least squares estimates of coefficients in linear probability models are consistent estimates of average probability derivatives, but standard error estimates are biased as a result of heteroskedasticity (Angrist and Krueger 1999). We report standard error estimates that are robust to any form of heteroskedasticity.
} 
discuss below, their inclusion has very little influence on the estimated effects of the suicidal behaviors on the productive activities.

A comparison of the results across the columns in Tables $2 \mathrm{~A}$ and $2 \mathrm{~B}$ shows that including the larger set of variables does not affect the sign or the statistical significance of the suicide coefficients in the work-school models. It is interesting to note that both the coefficients on suicide thoughts and attempts fall about one percentage points between columns 1 and 2 and then another half a percentage point between columns 2 and 3 and columns 4 and 5. But there is little change in the estimated effects between columns 4 and 5. The results from Tables $2 \mathrm{~A}$ and $2 \mathrm{~B}$ indicate that having suicide thoughts is associated with a decrease in the probability of being in a productive activity by a range of about 3 to 5 percentage points, and attempting suicide is associated with a decrease in the probability of being in a productive activity by a range of 9 to 12 percentage points. These figures represent fairly narrow ranges that point to the robustness of our estimates to additional covariates. In fact, these coefficients indicate that suicide thoughts and attempts are associated with a 4 to 6 percent and a 11 to 14 percent decrease in the probability of productive activities on average, respectively.

Another interesting finding is that the inclusion of the measures of depression has no appreciable effect on the magnitude of these coefficients. Also, using a specification with a rich set of control variables does not have much effect on the overall fit of the model as indicated by the Rsquared values. The fact that controlling for a large set of background characteristics and past suicidal behavior only slightly reduces the effect of current suicide thoughts and attempts can be interpreted to mean that unobserved heterogeneity accounts for only a small percentage of the effect of suicidal behavior on human capital activities. However, an alternative interpretation is that the additional variables, though statistically significant in the work-school equation, are not able to capture the omitted variables that are correlated with suicide thoughts and attempts. This suggests 
that the results from the two-state least squares (TSLS) estimation and the fixed effects models are necessary for drawing more solid conclusions.

Given that the coefficient estimates exhibit very little change between columns 4 and 5 and to minimize the risk of including potentially endogenous variables into our model, we pick the more parsimonious column 4 specification as opposed to column 5 as our preferred specification. It is interesting that current suicidal thoughts and attempts are associated with the decision to go to work or school even after holding constant past suicide attempts, and holding constant current and past suicide attempts of a family member. In fact, none of these other suicide measures are statistically significant predictors of the work-school decision in any OLS model. It appears that these factors primarily affect the outcomes of individuals through their influence on the current suicidal behaviors of individuals.

The other control variables in Tables $2 \mathrm{~A}$ and $2 \mathrm{~B}$ are usually consistent with our expectations and the results from the relevant literature. The indicators for depressive symptoms in Wave 1 and 3 are negatively associated with the probability of work-school. High standard test scores at high school and having a mother with more than a high school education are both associated with increases in working and schooling. Being in good physical health is a strong predictor of engaging in productive activities, while having spent time in foster care and having a father who was jailed in the past are negatively associated with these outcomes. Finally, having had trouble with teachers and other students in high school, having repeated a grade and having been suspended from school, and having run away from home in the past are all negatively associated with working or schooling, while having spent time on volunteering activities in high school is positively associated with these outcomes.

Next, we present the results from the models that estimate the determinants of suicide thoughts and attempts in Table 3. These also constitute our first stage models, which we use for the 
TSLS estimation. The first column displays the results for the determinants of suicide thoughts and the second column displays the results for the determinants of suicide attempts. In addition to the variables in our preferred specification as explained above, these models also include the instrumental variables - suicidal behavior of friends in the past 12 months from waves 1 and 3 . State and school fixed effects are also included.

The most striking result from Table 3 is that the suicidal behaviors of the peers and family members have a strong, positive relationship with the suicidal behaviors of respondents. For example, having a friend who attempted suicide in Wave 3 increases the probability of suicide thoughts by about 12 percentage points and suicide attempts by more than 3 percentage points. Similarly, having a family member who had attempted suicide in the past 12 months increases suicide thoughts by 9 percentage points and suicide attempts by 3 percentage points. A past suicide attempt is highly associated with current suicidal behavior, increasing suicide thoughts and suicide attempts by about 8 and 4 percentage points, respectively. This result suggests that mental health problems during adolescence may have persistent effects on the mental health of individuals even after they enter adulthood. The past suicidal experiences of the friends and family members have insignificant and negligible effects on own suicidal behavior. The effects of these variables are likely to be captured by the individual's own suicidal behavior in the past. Nevertheless, the coefficients on the two instrumental variables - suicide attempts by friends in waves 1 and 3 - are jointly significant at less than 1 percent level.

A few other variables are worth mentioning for their efficacy in predicting suicide thoughts and attempts. Individuals in the top $20^{\text {th }}$ percent of the CES-D distribution (the depression indicator) are more likely to have suicide thoughts and attempts. Having a standardized test score in higher quartiles actually increases the probability of having suicide thoughts over those individuals having scores in the bottom quartile. It is interesting to note that the effect monotonically increases as one 
moves in the direction of higher test scores. However, the differences disappear when suicidal attempts are considered. Having suffered any type of abuse as a child is positively related to current suicide thoughts and attempts. A similar pattern is observed for the effect of having a father who was ever jailed, although the effect is only statistically significant for suicide thoughts. Being married and being in good physical health are negatively related to both suicide thoughts and attempts.

Table 4 shows the results from two-stage least squares (TSLS) estimation of the effect of suicidal behaviors on the outcome variable for our preferred specification. ${ }^{12}$ Suicide attempts by friends in waves 1 and 3 serve as the instruments. Intuitively, these instruments are plausible because there is existing strong evidence that peer suicide affects one's own state of mental health and resulting behaviors. For example, in a sample of high school students, Ho et al. (2000) find that there is a high risk of suicidal behaviors and psychiatric disturbances among peers of individuals who completed suicide. Cerel et al. (2005) find that adolescents who are exposed to peer suicide are more likely to have suicidal thoughts and attempts and to engage in other destructive behavior such as substance use.

While it is not hard to imagine that a friend's suicidal behavior strongly predicts an individual's own behavior, we believe it is unlikely that the suicidal behavior of a friend will have direct effects on one's own labor market and schooling decisions above and beyond the effects on the individual's own suicidal behavior, particularly when a measure of depression is held constant. However, one possibility is that youths react to peer suicide by engaging in risky behavior, such as substance abuse, and if that behavior has a direct effect on labor market and school outcomes, the exogeneity of the instruments may be called into question. One can guard against this criticism by

\footnotetext{
12 To economize on space, we present only the key coefficients. The coefficients from other variables largely remain same with those in Tables 3A and 3B. The TSLS results for other specifications are very similar to those presented in the paper. The full results are available from the authors upon request.
} 
including controls for current risky behavior, such as drug and alcohol use. The problem is that these variables may themselves be endogenous to our outcome measures. This is why we control for measures of past drug and alcohol use in the models. Despite the potential endogeneity problem, we re-estimated our models including current drug and alcohol use. These models did not alter the estimates of suicidal behavior in any significant way. ${ }^{13}$

The validity of our instrumental variables analyses hinges on the assumption that friends' suicidal behaviors are strongly associated with the individuals' own suicidal behaviors, while having no direct association with the outcome measures that we examine. The strength of the instruments can be gauged in two ways - theoretically and empirically. As reported at the bottom of Table 4, the two instruments, a friend's attempt in the first wave and a friend's attempt in the third wave, are strong predictors of current suicidal behaviors as indicated by the F-statistics. The overidentification test (Hansen $\mathbf{J}$ statistic) indicates that the instruments are appropriately excluded from the second stage. However, the Durbin-Wu-Hausman tests are not rejected for either of the model, indicating that the OLS and IV coefficients are not statistically different from each other. Indeed, the TSLS results are qualitatively similar to those in Tables $2 \mathrm{~A}$ and $2 \mathrm{~B}$, but the magnitudes are much larger. Having suicide thoughts decreases the probability of being in a productive activity by a range of about 21 percentage points, while a suicide attempt decreases the probability of being in a productive activity by about 74 percentage points. Taken together, these tests suggest that the endogeneity of suicidal behavior does not improve upon OLS estimates after controlling all these variables and the fixed effects. We also prefer OLS over the IV results because OLS estimates have lower standard errors (Cawley 2004, Chou et al. 2005).

\footnotetext{
${ }^{13}$ Reporting bias may also present a problem for the instruments, that is, individuals who are suicidal themselves may be more likely to report that they had suicidal friends. Unfortunately, we cannot know for sure whether reporting bias plays an important role or not given the data set that we have.
} 
The results from the twin and sibling fixed effects analyses are presented in Table 5. Fixed effects models are a powerful way to control for omitted variable bias and they are used increasingly in economics (e.g. Currie and Stabile 2007, Currie and Tekin 2006). Only the coefficients on variables of interest are shown for brevity. We believe the results of these specifications are reliable since the fixed effects can control for a host of unmeasured, time invariant characteristics that might be correlated with the suicidal behaviors and the outcome measures. Obviously, the number of control variables in the these models is much lower than the OLS and IV models as many of the background variables exhibit no variation between twin and sibling pairs.

As documented in Table 5, these results are usually consistent with those from the OLS models. Looking at the sibling fixed effects, suicidal thoughts and attempts are associated with about a 9 percent decrease in the probability of engaging in productive activities, although the latter is not estimated with much precision. The estimates from the twin fixed effects are larger than the OLS and sibling fixed effects estimates, although they are qualitatively similar. Suicide thoughts and attempts are associated with 19 and 31 percent decreases in the probability of engaging in productive activities, respectively. Note that the identification in fixed effects models comes from discordant reports of suicide thoughts and attempts between pairs and the number of discordant pairs for the twin fixed effects model is expectedly low. In particular, there are only 10 twin pairs with discordant reports of suicide attempts out of a total 380 twin pairs, while the number of twin pairs with discordant reports of suicide thoughts is 45 . This may explain in part why the estimates in the twin fixed effects model are larger than both the OLS and the sibling fixed effects estimates. Nevertheless, the qualitative similarity between the OLS and the fixed effects estimates suggest that measurement error is unlikely to be the source driving the estimates. The fact that most of the fixed effects estimates exceed the OLS ones further supports this argument, since, as argued in Currie and 
Stabile (2007), the random measurement error in suicidal behavior would be expected to reduce the size of fixed effects estimates relative to the OLS estimates.

\section{Specification Checks}

One can argue that family members' suicide attempts may be endogenous to the individuals' own suicidal behavior. For example, a respondent may attempt suicide and a parent may follow in response. If this is the case, our results from the OLS and twin-fixed effects could be biased. However, the coefficients on the family members' suicide attempts are not statistically significant in any of our models. In fact, our results basically remain the same when we exclude these variables from our models.

Another useful exercise is to estimate models that only includes the past suicidal behavior since these models are not subject to any reverse causality problem to begin with. Also, having both the current and past suicidal behavior in the same models might be problematic due to multicollinearity. Therefore, we estimated our models excluding the current suicidal behavior variables. In these models, the past suicidal attempt has a negative coefficient in the work-school model.

In order to see if suicidal behaviors have a differential impact on the decisions to go to work, school, or both, we estimate a multinomial logit model in Table 6. In doing this, we have separated the dichotomous indicator of being in a productive activity into its possible components. The decisions modeled in this table are 1) school, 2) work, 3) school and work together, or 4) no work and no school, which is the omitted reference category. Note that estimating a fixed effects multinomial logit model in our context may be problematic because it has been shown by Monte Carlo simulations that the fixed effects estimator produce a large finite sample bias in discrete choice models when the number of observations in each group is very small (Green 2002). In our 
case, there are two individuals in each twin pair by definition. Therefore, the fixed effects model in this context will be unreliable so we rely on the rich set of variables in our preferred specification from Tables $2 \mathrm{~A}$ and $2 \mathrm{~B}$ to help control for omitted variables. Since we do not explicitly account for the potential endogeneity of the suicide behaviors in the multinomial logit, we treat these results as merely demonstrative and do not place much emphasis on the magnitude of the coefficients.

The estimates from the multinomial logit model are presented in Table 6 . The coefficients in the first three columns show the results for suicidal thoughts and the coefficients in the last three columns show the results for suicide attempts. The omitted outcome in the multinomial logit models is no-work and no-school. The results indicate that suicidal behaviors as measured by suicide thoughts and suicide attempts decrease the probability that an individual is engaged in work, school, or both of these activities in comparison to the omitted category of not working and not going to school.

\section{Conclusion}

This paper expands our understanding of the link between mental health and human capital formation by providing insights into the effects of suicidal behavior on the outcome of productive activities of young adults. The suicidal behaviors are measured as suicide thoughts and suicide attempts, and productive activities are measured as engaging in work and/or schooling activities. Obtaining a reliable effect of suicidal behavior on productivity outcomes can be problematic because of the presence of unobserved heterogeneity and a potential reverse causality. In this paper, we employ three strategies to eliminate these problems. First, we control for a very large set of background variables that are likely to be correlated with both suicidal behavior and our outcome measure. Second, we use instrumental variables to control for both unobserved heterogeneity and 
reverse causality. Finally, we estimate models with family fixed effects to sweep out any unobservables that are common to both twins and siblings.

The results from all three approaches suggest that suicide thoughts and attempts have negative effects on the work and schooling decisions of young adults. All of the effects are found to be robust to different sets of control variables and various specification tests. It is also interesting to note that the size of the effect of suicide attempt is larger than that of the suicidal thoughts. This is a sensible result given that suicide attempt is likely to be an indicator for a more serious mental health problem than having suicidal thoughts only.

The results shown in this paper highlight the costs to individuals and to society resulting from suicidal behaviors. The fact that all of the three strategies that we employ to tease out both the unobserved heterogeneity and reverse causality points to a negative link between the suicidal behaviors and the outcome measure makes us believe that the detrimental effects are consistent with a causal explanation. Furthermore, the small and statistically insignificant coefficients on past suicide attempts arising from models that both include and exclude current suicidal behaviors suggest that there is no long term effect of past attempts (i.e. attempts during high school) on future human capital formation. This result should be interpreted with caution, however, as teenagers who attempt suicide may receive mental health treatment that prevents future deleterious effects. 


\section{References}

Alexopoulos, George S. Martha L. Bruce, James Hull, Jo Anne Sirey, and Tatsuyuki Kakuma. 1999. Clinical Determinants of Suicidal Ideation and Behavior in Geriatric Depression. Archives of General Psychiatry 56:1048-1053.

Anderson, R. N., and B. L. Smith. 2003. Deaths: leading causes for 2001. National Vital Statistics Report, 52(9):1-86.

Angrist, Joshua D., and Alan B. Krueger. 1999. Empirical Strategies in Labor Economics, in Handbook of Labor Economics Volume 3A, Orley Ashenfelter and David Card, eds., Amsterdam:

Elsevier.

Bartel, A. and P. Taubman. 1979. Health and Labor Market Success: The Role of Various Diseases. Review of Economics and Statistics 61(1):1-8.

Bartel, A. and P. Taubman. 1986. Some Economic and Demographic Consequences of Mental Illness. Journal of Labor Economics 4(2):243-56.

Boergers, J., A. Spirito, and D. Donaldson. 1988. Reasons for Adolescent Suicide Attempts: Associations with Psychological Functioning. Journal of the American Academy of Child and Adolescent Psychiatry 37:1287-1293.

Borst, S. R., and G. G. Noam. 1989. Suicidality and Psychopathology in Hospitalized Children and Adolescents. Acta Paedopsychiatrica 52:165-175.

Cawley, John. 2004. The Impact of Obesity on Wages. The Journal of Human Resources 39(2):451-474.

Center for Disease Control and Prevention. 1992. Youth Suicide Prevention Programs: A Resource Guide. U.S Department of Health and Human Services, Public Health Service, National Center for Injury Prevention and Control. 
Cerel, J., T. A. Roberts, and W. J. Nilsen. 2005. Peer suicidal behavior and adolescent risk behavior. The Journal of Nervous and Mental Disease 193(4):237-43.

Chatterji, P., D. Dave, R. Kaestner, and S. Markowitz. 2004. Alcohol Abuse and Suicide Attempts Among Youth. Economics and Human Biology 2(2):159-180.

Civic, D., and V. L. Holt. 2000. Maternal depressive symptoms and child behavior problems in a nationally representative birthweight sample . Maternal and Child Health Journal 4: 215-21.

Conti D. J., and W. N. Burton. 1994. Economic Impact of Depression in a Workplace. Journal of Occupational Environmental Medicine 36:983-988.

Currie, Janet, and Erdal Tekin. 2006. Does Child Abuse Cause Crime? National Bureau of Economic Research Working Paper No. 12171.

Currie, Janet, and Mark Stabile. 2007. Mental Health in Childhood and Human Capital. National Bureau of Economic Research Working Paper No. 13217.

Cutler, David M., Edward L. Glaeser, and Karen E. Norberg. 2001. Explaining The Rise in Youth Suicide. In Risky Behavior among Youth, edited by J. Gruber. University of Chicago Press, Chicago IL.

Dube, Shanta,Vincent Felitti, Maxia Dong, W.H. Giles, and Robert Anda. 2003. The Impact of Adverse Childhood Experiences on Health Problems: Evidence from Four Birth Cohorts Dating Back to 1900. Preventive Medicine 37(3):268-277.

Eaton, W. W., C. Muntaner, C. Smith, A. Tien, and M. Ybarra. 2003. Center for epidemiologic studies depression scale: Review and revision (CESD and CESDR). In The use of psychological testing for treatment planning and outcomes assessment, $3^{\text {rd }}$ edition, chapter 40 , volume III, edited by M.E. Maruish. Mahwah, NJ : Lawrence Erlbaum Associates.

Ettner, S., R. Frank, and R. Kessler. 1997. The Impact of Psychiatric Disorders on Labor Market Outcomes. Industrial and Labor Relations Review 51(1):64-81. 
Felitti, Vincent J., Robert Anda, Dale Nordenberg, David Williamson, Alison Spitz, Valerie Edwards, Mary Koss, and James Marks. 1998. Relationship of Childhood Abuse and Household Dysfunction to Many of the Leading Causes of Death in Adults. American Journal of Preventive Medicine 14(4):245-258.

Fergusson, David M and Lianne J. Woodward. 2002. Mental Health, Educational, and Social Role Outcomes of Adolescents With Depression. Archives of General Psychiatry 59:225-31.

Frank, R., and P. Gertler. 1991. An Assessment of Measurement Error Bias for Estimating the Effect of Mental Distress on Income. Journal of Human Resources 26(1):154-164.

French, M., and G. Zarkin. 1998. Mental Health, Absenteeism and Earnings at a Large Manufacturing Worksite. Journal of Mental Health Policy and Economics 1:161-172.

Goldsmith, S. K., T. C. Pellmar, A. M. Kleinman, and W. E. Bunney, editors. 2002. Reducing Suicide, A National Imperative. The National Academies Press, Washington, D.C.

Greene, William. 2002. The Bias of the Fixed Effects Estimator in Nonlinear Models. Working Paper, Department of Economics, New York University, October.

Greenberg, P. E., L. E. Stiglin, S. N. Finkelstein, and E. R. Berndt. 1990. The Economic Burden of Depression in 1990. Journal of Clinical Psychiatry 2:32-35.

Hamermesh, Daniel S, and Neal M. Soss. 1974. An Economic Theory of Suicide. Journal of Political Economy 82(1):83-98.

Hamilton, V.H., P. Merrigan and Eric Dufresne. 1997. Down and Out: Estimating the Relationship Between Mental Health and Unemployment. Health Economics 6:397-406.

Ho, T. P., P.W. Leung, S. F. Hung, C. C. Lee, and C. P. Tang. 2000. The Mental Health of the Peers of Suicide Completers and Attempters. Journal of Child Psychology and Psychiatry 41(3):301-8. Johnson, J., M. M. Weissman, and G. L. Klerman. 1990. Panic Disorder, Comorbidity, and Suicide Attempts. Archives of General Psychiatry 47:805-808. 
Kessler, R. C., P. A. Berglund, C. L. Foster, W. B. Saunders, P. E. Stang, and E. E. Walters. 1997. Social Consequences of Psychiatric Disorders, II: Teenage parenthood. American Journal of Psychiatry 154(10):1405-11.

Lubell, K. M., M. H. Swahn, A. E. Crosby, and S. R. Kegler. 2004. Methods of suicide among persons aged 10-19 years-United States, 1992-2001. Morbidity and Mortality Weekly Report 53(22):471-473. Available online from: URL: http://www.cdc.gov/mmwr/PDF/wk/mm5322.pdf. Marcotte, Dave E. 2003. The Economics of Suicide, Revisited. Southern Economic Journal 69(3):628-643.

Maris, R. W., A. L. Berman, J. T. Maltsberger, and R. I. Yufit, editors. 1992. Assessment and Prediction of Suicide. New York: The Guilford Press.

Marmorstein, N. R., and W. G. Iacono. 2001. An Investigation of Female Adolescent Twins with Both Major Depression and Conduct Disorder. Journal of the American Academy of Child and Adolescent Psychiatry 40(3):299-306.

Melhem, N. M., N. Day, M. K. Shear, R. Day, C. F. Reynolds 3rd, and D. Brent. 2004. Traumatic Grief among Adolescents Exposed to a Peer's Suicide. The American Journal of Psychiatry 161(8):1411-6.

Miller, Ted R. 1995. Databook on Nonfatal Injury: Incidence, Costs, and Consequences.

Washington D.C.: Urban Institute Press. pp. 166-67.

Miller T. R., K. L. Covington, and A. F. Jensen. 1999. Costs of Injury by Major Cause, United States, 1995: Cobbling Together Estimates. In Measuring the Burden of Injuries: Proceedings of a Conference in Noordwijkerhout, Netherlands, May 13-15, 1998, edited by S. Mulder. Available on line at: http://www.edarc.org/pubs/tables/youthsui.htm

Mullahy, J. and J. Sindelar. 1990. Gender Differences in the Effects of Mental Health on Labor Force Participation. In Research in Human Capital and Development 6:125-146. JAI Press Inc. 
Radloff, L. 1977. The CES-D Scale: A Self-Reported Depression Scale for Research in the General Population. Applied Psychological Measurement 1:385-401.

Overbeek, Geertjan, Wilma Vollebergh, Rutger C. M. E. Engels, Wim Meeus. 2003. Young adults’ relationship transitions and the incidence of mental disorders: A three-wave longitudinal study. Social Psychiatry \& Psychiatric Epidemiology 38(12):669-676.

Shaffer, D, and L. Craft. 1999. Methods of Adolescent Suicide Prevention. Journal of Clinical Psychiatry 69(suppl. 2):70-74.

Chou, Shin-Yi, Inas Rashad, and Michael Grossman. 2005. Fast-Food Restaurant Advertising on Television and Its Influence on Childhood Obesity. National Bureau of Economic Research Working Paper No. 11879.

Simon, G. E., and M. Von Korff. 1998. Suicide Mortality among Patients Treated for Depression in an Insured Population. American Journal of Epidemiology 147(2):155-160.

Slap, G., E. Goodman, and B. Huang. 2001. Adoption as a Risk Factor for Attempted Suicide during Adolescence. Pediatrics 108(2):E30.

Stoep, A.V., N. S. Weiss, E. S. Kuo, D. Cheney, and P. Cohen. 2003. What Proportion of Failure to Complete Secondary School in the U.S. Population is Attributable to Adolescent Psychiatric Disorder? Journal of Behavioral Health Services \& Research 30(1):119-24.

U.S. Department of Education. 2001. $23^{\text {rd }}$ Annual Report to Congress on the Implementation of the Individuals with Disabilities Education Act. Washington, D.C.

Veltman, Marijcke, and Kevin D. Browne. 2001. Three Decades of Child Maltreatment Research: Implications for the School Years. Trauma, Violence, and Abuse 2(3):215-239. 
Table 1

\section{Definitions and Descriptive Statistics}

\begin{tabular}{|c|c|c|c|c|}
\hline Variable & Definition & $\begin{array}{l}\text { Full } \\
\text { Sample }\end{array}$ & $\begin{array}{l}\text { Suicide } \\
\text { thoughts }=1\end{array}$ & $\begin{array}{l}\text { Suicide } \\
\text { thoughts }=0\end{array}$ \\
\hline Work-school & $\begin{array}{l}\text { Dummy variable }=1 \text { if working and/or attending school, }=0 \\
\text { otherwise }\end{array}$ & $\begin{array}{l}0.834 \\
(0.372)\end{array}$ & $\begin{array}{l}0.792 * * * \\
(0.406)\end{array}$ & $\begin{array}{l}0.837 \\
(0.370)\end{array}$ \\
\hline Suicide thoughts & $\begin{array}{l}\text { Dummy variable }=1 \text { if ever thought seriously about committing } \\
\text { suicide during the past } 12 \text { months, }=0 \text { otherwise }\end{array}$ & $\begin{array}{l}0.059 \\
(0.235)\end{array}$ & $\begin{array}{l}1.000 \\
(0.000)\end{array}$ & $\begin{array}{l}0.000 \\
(0.000)\end{array}$ \\
\hline Suicide attempt & $\begin{array}{l}\text { Dummy variable }=1 \text { if actually attempted suicide during the past } 12 \\
\text { months, }=0 \text { otherwise }\end{array}$ & $\begin{array}{l}0.016 \\
(0.124)\end{array}$ & $\begin{array}{l}0.265^{* * *} \\
(0.442)\end{array}$ & $\begin{array}{l}0.000 \\
(0.000)\end{array}$ \\
\hline Suicidal friend & $\begin{array}{l}\text { Dummy variable }=1 \text { if any friends tried to kill themselves, }=0 \\
\text { otherwise }\end{array}$ & $\begin{array}{l}0.067 \\
(0.250)\end{array}$ & $\begin{array}{l}0.223 * * * \\
(0.416)\end{array}$ & $\begin{array}{l}0.057 \\
(0.233)\end{array}$ \\
\hline Suicidal family & $\begin{array}{l}\text { Dummy variable }=1 \text { if any family members tried to kill themselves, } \\
=0 \text { otherwise }\end{array}$ & $\begin{array}{l}0.029 \\
(0.167)\end{array}$ & $\begin{array}{l}0.095 * * * \\
(0.294)\end{array}$ & $\begin{array}{l}0.025 \\
(0.155)\end{array}$ \\
\hline Suicide attempt_w1 & $\begin{array}{l}\text { Dummy variable }=1 \text { if actually attempted suicide during the past } 12 \\
\text { months (reported at Wave } 1 \text { ), }=0 \text { otherwise }\end{array}$ & $\begin{array}{l}0.037 \\
(0.189)\end{array}$ & $\begin{array}{l}0.107 * * * \\
(0.310)\end{array}$ & $\begin{array}{l}0.032 \\
(0.178)\end{array}$ \\
\hline Suicidal friend_w1 & Dummy variable $=1$ if any friends tried to kill themselves (reported & 0.175 & $0.245^{* * *}$ & 0.171 \\
\hline
\end{tabular}


Suicidal family_w1 Dummy variable $=1$ if any family members tried to kill themselves

$0.044 \quad 0.064 * * * \quad 0.042$

(reported at Wave 1), $=0$ otherwise

$\begin{array}{lll}(0.204) & (0.245) & (0.201) \\ 0.255 & 0.230^{*} & 0.256 \\ (0.436) & (0.421) & (0.437) \\ 0.406 & 0.348^{* * *} & 0.410 \\ (0.491) & (0.477) & (0.492)\end{array}$

No religion

Dummy variable $=1$ if no religion or agnostic, $=0$ otherwise

0.205

$0.281 * * *$

0.200

$(0.403)$

$(0.450)$

$(0.400)$

Other religion $^{\text {a }}$

Dummy variable $=1$ if other religion, $=0$ otherwise

0.135

0.141

0.134

$(0.341)$

(0.349)

$(0.341)$

Healthy

Dummy variable $=1$ if in good physical health, $=0$ otherwise

$0.954 \quad 0.888 * * * \quad 0.958$

(0.209) (0.316)

Any abuse

Dummy variable $=1$ if experienced sexual abuse, physical abuse, or

0.245

$0.419 * * *$

0.234

neglect from parents or other adult caregivers by the start of 6th

(0.430)

(0.494)

grade, $=0$ otherwise

Foster

Dummy variable $=1$ if ever spent time in foster care, $=0$ otherwise 


\begin{tabular}{|c|c|c|c|c|}
\hline \multirow[t]{2}{*}{ Jailed father } & Dummy variable $=1$ if father ever spent time in prison, $=0$ otherwise & 0.147 & $0.233 * * *$ & 0.142 \\
\hline & & $(0.354)$ & $(0.423)$ & $(0.349)$ \\
\hline \multirow[t]{2}{*}{ Cocaine_w1 } & Dummy variable $=1$ if ever used cocaine $($ reported at Wave 1$),=0$ & 0.032 & $0.052 * * *$ & 0.031 \\
\hline & otherwise & $(0.175)$ & $(0.222)$ & $(0.172)$ \\
\hline \multirow[t]{2}{*}{ Marijuana_w1 } & Dummy variable $=1$ if ever used marijuana( reported at Wave 1$),=0$ & 0.277 & $0.331 * * *$ & 0.274 \\
\hline & otherwise & $(0.448)$ & $(0.471)$ & $(0.446)$ \\
\hline \multirow[t]{2}{*}{ Age } & Age in years & 21.956 & $21.649 * * *$ & 21.975 \\
\hline & & $(1.772)$ & $(1.837)$ & $(1.776)$ \\
\hline \multirow[t]{2}{*}{ Age $18^{a}$} & Dummy variable $=1$ if 18 years of age,$=0$ otherwise & 0.010 & 0.014 & 0.009 \\
\hline & & $(0.098)$ & $(0.118)$ & $(0.097)$ \\
\hline \multirow[t]{2}{*}{ Age19 } & Dummy variable $=1$ if 19 years of age, $=0$ otherwise & 0.095 & $0.138 * * *$ & 0.092 \\
\hline & & $(0.293)$ & $(0.345)$ & $(0.289)$ \\
\hline \multirow[t]{2}{*}{ Age20 } & Dummy variable $=1$ if 20 years of age, $=0$ otherwise & 0.132 & $0.156^{* *}$ & 0.131 \\
\hline & & $(0.339)$ & $(0.363)$ & $(0.337)$ \\
\hline \multirow[t]{2}{*}{ Age 21} & Dummy variable $=1$ if 21 years of age,$=0$ otherwise & 0.161 & 0.165 & 0.161 \\
\hline & & $(0.368)$ & $(0.371)$ & $(0.368)$ \\
\hline \multirow[t]{2}{*}{ Age22 } & Dummy variable $=1$ if 22 years of age, $=0$ otherwise & 0.189 & 0.191 & 0.187 \\
\hline & & $(0.391)$ & $(0.393)$ & $(0.391)$ \\
\hline
\end{tabular}




\begin{tabular}{|c|c|c|c|c|}
\hline \multirow[t]{2}{*}{ Age23 } & Dummy variable $=1$ if 23 years of age, $=0$ otherwise & 0.191 & $0.136 * * *$ & 0.195 \\
\hline & & $(0.393)$ & $(0.343)$ & $(0.396)$ \\
\hline \multirow[t]{2}{*}{ Age24 } & Dummy variable $=1$ if 24 years of age, $=0$ otherwise & 0.163 & 0.145 & 0.164 \\
\hline & & $(0.369)$ & $(0.352)$ & $(0.370)$ \\
\hline \multirow[t]{2}{*}{ Age25 } & Dummy variable $=1$ if 25 years of age, $=0$ otherwise & 0.051 & 0.052 & 0.051 \\
\hline & & $(0.220)$ & $(0.222)$ & $(0.220)$ \\
\hline \multirow[t]{2}{*}{ Age26+ } & Dummy variable $=1$ if 26 years of age, $=0$ otherwise & 0.008 & 0.004 & 0.008 \\
\hline & & $(0.090)$ & $(0.059)$ & $(0.091)$ \\
\hline \multirow[t]{2}{*}{ Male } & Dummy variable $=1$ if male, $=0$ otherwise & 0.468 & 0.442 & 0.470 \\
\hline & & $(0.499)$ & $(0.497)$ & $(0.499)$ \\
\hline \multirow[t]{2}{*}{ White } & Dummy variable $=1$ if white,$=0$ otherwise & 0.662 & $0.713 * * *$ & 0.658 \\
\hline & & $(0.473)$ & $(0.453)$ & $(0.474)$ \\
\hline \multirow[t]{2}{*}{ Black } & Dummy variable $=1$ if black, $=0$ otherwise & 0.227 & $0.178 * * *$ & 0.230 \\
\hline & & $(0.419)$ & $(0.383)$ & $(0.421)$ \\
\hline \multirow[t]{2}{*}{ Other race ${ }^{\mathrm{a}}$} & Dummy variable $=1$ if other race, $=0$ otherwise & 0.111 & 0.109 & 0.112 \\
\hline & & $(0.315)$ & $(0.312)$ & $(0.315)$ \\
\hline \multirow[t]{2}{*}{ Hispanic } & Dummy variable $=1$ if Hispanic ethnicity, $=0$ otherwise & 0.161 & 0.149 & 0.162 \\
\hline & & $(0.368)$ & $(0.357)$ & $(0.369)$ \\
\hline
\end{tabular}




\begin{tabular}{|c|c|c|c|c|}
\hline \multirow[t]{2}{*}{ U.S. born } & Dummy variable $=1$ if born in the U.S., $=0$ otherwise & 0.920 & 0.926 & 0.920 \\
\hline & & $(0.271)$ & $(0.262)$ & $(0.271)$ \\
\hline \multirow[t]{2}{*}{ PVT_w1A ${ }^{a}$} & Standard Peabody test score ranking from Wave 1 in the lowest 25 & 0.250 & $0.177 * * *$ & 0.255 \\
\hline & percentile & $(0.434)$ & $(0.382)$ & $(0.436)$ \\
\hline \multirow[t]{2}{*}{ PVT_w1B } & Standard Peabody test score ranking from Wave 1 in the $25-50$ & 0.257 & 0.257 & 0.256 \\
\hline & percentile & $(0.438)$ & $(0.437)$ & $(0.437)$ \\
\hline \multirow[t]{2}{*}{ PVT_w1C } & Standard Peabody test score ranking from Wave 1 in the $50-75$ & 0.233 & 0.257 & 0.231 \\
\hline & percentile & $(0.423)$ & $(0.437)$ & $(0.422)$ \\
\hline \multirow[t]{2}{*}{ PVT_w1D } & Standard Peabody test score ranking from Wave 1 in the highest 25 & 0.260 & $0.310 * * *$ & 0.257 \\
\hline & percentile & $(0.439)$ & $(0.463)$ & $(0.437)$ \\
\hline \multirow[t]{2}{*}{ Married } & Dummy variable $=1$ if married, $=0$ otherwise & 0.171 & $0.099 * * *$ & 0.176 \\
\hline & & $(0.377)$ & $(0.299)$ & $(0.381)$ \\
\hline \multirow[t]{2}{*}{ Mother high school- } & Dummy variable $=1$ if mother has less than a high school degree & 0.159 & 0.139 & 0.160 \\
\hline & reported at Wave $1,=0$ otherwise & $(0.366)$ & $(0.346)$ & $(0.367)$ \\
\hline \multirow[t]{2}{*}{ Mother high school } & Dummy variable $=1$ if mother has a high school degree reported at & 0.352 & 0.353 & 0.351 \\
\hline & Wave $1,=0$ otherwise & $(0.477)$ & $(0.478)$ & $(0.477)$ \\
\hline \multirow[t]{2}{*}{ Mother high school+ } & Dummy variable $=1$ if mother has more than a high school degree at & 0.489 & 0.508 & 0.488 \\
\hline & Wave $1,=0$ otherwise & $(0.500)$ & $(0.500)$ & $(0.500)$ \\
\hline
\end{tabular}




\begin{tabular}{|c|c|c|c|c|}
\hline \multirow[t]{2}{*}{ Non-wage } & Non-wage income in the past year in dollars & 1909.3 & 1662.2 & 1924.8 \\
\hline & & $(14238.2)$ & $(7768.9)$ & $(14551.6)$ \\
\hline \multirow[t]{2}{*}{ Non-wage $1^{\mathrm{a}}$} & Dummy variable $=1$ if non-wage income is $<0,=0$ otherwise & 0.031 & 0.039 & 0.030 \\
\hline & & $(0.173)$ & $(0.196)$ & $(0.171)$ \\
\hline \multirow[t]{2}{*}{ Non-wage2 } & Dummy variable $=1$ if non-wage income is $=0,=0$ otherwise & 0.536 & $0.507^{*}$ & 0.538 \\
\hline & & $(0.499)$ & $(0.500)$ & $(0.499)$ \\
\hline \multirow[t]{2}{*}{ Non-wage 3} & Dummy variable $=1$ if $0<$ non-wage income $<=1000,=0$ otherwise & 0.158 & 0.161 & 0.158 \\
\hline & & $(0.365)$ & $(0.367)$ & $(0.365)$ \\
\hline \multirow[t]{2}{*}{ Non-wage4 } & Dummy variable $=1$ if $1000<$ non-wage income $<=2000,=0$ & 0.067 & 0.072 & 0.067 \\
\hline & otherwise & $(0.250)$ & $(0.259)$ & $(0.249)$ \\
\hline \multirow[t]{2}{*}{ Non-wage5 } & Dummy variable $=1$ if $2000<$ non-wage income $<=5000,=0$ & 0.098 & 0.103 & 0.97 \\
\hline & otherwise & $(0.297)$ & $(0.305)$ & $(0.296)$ \\
\hline \multirow[t]{2}{*}{ Non-wage6 } & Dummy variable $=1$ if $5000<$ non-wage income $<=10000,=0$ & 0.054 & $0.070 * *$ & 0.053 \\
\hline & otherwise & $(0.227)$ & $(0.255)$ & $(0.225)$ \\
\hline \multirow[t]{2}{*}{ Non-wage7 } & Dummy variable $=1$ if $10000<$ non-wage income,$=0$ otherwise & 0.056 & 0.047 & 0.056 \\
\hline & & $(0.230)$ & $(0.212)$ & $(0.231)$ \\
\hline \multirow[t]{2}{*}{ Depression_w1 } & Dummy variable $=1$ if the individual's CES-D score places them at & 0.206 & $0.315^{* * *}$ & 0.199 \\
\hline & the $80^{\text {th }}$ percentile or higher in the sample distribution for Wave 1 & $(0.404)$ & $(0.465)$ & $(0.399)$ \\
\hline
\end{tabular}




\begin{tabular}{|c|c|c|c|c|}
\hline \multirow[t]{2}{*}{ Depression_w3 } & Dummy variable $=1$ if the individual's CES-D score places them at & 0.216 & $0.446 * * *$ & 0.202 \\
\hline & the $80^{\text {th }}$ percentile or higher in the sample distribution for Wave 3 & $(0.412)$ & $(0.497)$ & $(0.402)$ \\
\hline \multirow[t]{2}{*}{ Volunteer work } & Dummy variable $=1$ if did volunteer work as a teenager & 0.365 & 0.362 & 0.365 \\
\hline & & $(0.481)$ & $(0.481)$ & $(0.481)$ \\
\hline \multirow[t]{2}{*}{ Ran away } & Dummy variable $=1$ if ran away from home when in high school & 0.079 & $0.138 * * *$ & 0.075 \\
\hline & & $(0.270)$ & $(0.345)$ & $(0.264)$ \\
\hline \multirow[t]{2}{*}{ Counseling_w1 } & Dummy variable $=1$ if had psychological or emotional counseling in & 0.117 & $0.198 * * *$ & 0.112 \\
\hline & the past 12 months in Wave 1 & $(0.321)$ & $(0.399)$ & $(0.315)$ \\
\hline Drug abuse & Dummy variable $=1$ if participated in drug abuse program in Wave 1 & 0.026 & $0.040 * * *$ & 0.025 \\
\hline program_w1 & & $(0.159)$ & $(0.196)$ & $(0.156)$ \\
\hline \multirow[t]{2}{*}{ Drunk_w1 } & Dummy variable $=1$ if was drunk at least once a week past 12 & 0.052 & $0.064 * * *$ & 0.051 \\
\hline & months in Wave 1 & $(0.221)$ & $(0.245)$ & $(0.219)$ \\
\hline \multirow[t]{2}{*}{ Alcohol at home_w1 } & Dummy variable $=1$ if alcohol was easily available at home - Wave & 0.296 & $0.347 * * *$ & 0.293 \\
\hline & 1 & $(0.457)$ & $(0.476)$ & $(0.455)$ \\
\hline \multirow[t]{2}{*}{ Drug at home_w1 } & Dummy variable $=1$ if drugs were easily available at home - Wave 1 & 0.031 & $0.048 * * *$ & 0.030 \\
\hline & & $(0.175)$ & $(0.215)$ & $(0.172)$ \\
\hline \multirow[t]{2}{*}{ Repeat grade_w1 } & Dummy variable $=1$ if repeated a grade as of Wave 1 & 0.207 & 0.200 & 0.207 \\
\hline & & $(0.405)$ & $(0.401)$ & $(0.405)$ \\
\hline
\end{tabular}




\begin{tabular}{|c|c|c|c|c|}
\hline School & Dummy variable $=1$ if suspended from school in Wave 1 & 0.271 & 0.291 & 0.270 \\
\hline suspension_w1 & & $(0.445)$ & $(0.455)$ & $(0.445)$ \\
\hline Trouble with & Dummy variable $=1$ if had trouble with teachers everyday in Wave 1 & 0.076 & $0.092 *$ & 0.075 \\
\hline teachers_w1 & & $(0.265)$ & $(0.289)$ & $(0.263)$ \\
\hline Trouble with & Dummy variable $=1$ if had trouble with students everyday in Wave 1 & 0.077 & $0.118 * * *$ & 0.074 \\
\hline students_w1 & & $(0.266)$ & $(0.323)$ & $(0.262)$ \\
\hline Felt close to & Dummy variable $=1$ if felt close to people at school in Wave 1 & 0.125 & $0.171 * * *$ & 0.123 \\
\hline people_w1 & & $(0.331)$ & $(0.377)$ & $(0.328)$ \\
\hline Felt part of & Dummy variable $=1$ if felt part of school in Wave 1 & 0.118 & $0.186^{* * *}$ & 0.114 \\
\hline school_w1 & & $(0.323)$ & $(0.390)$ & $(0.318)$ \\
\hline Felt students & Dummy variable $=1$ if felt that students were prejudiced in Wave 1 & 0.329 & 0.308 & 0.330 \\
\hline prejudice_w1 & & $(0.470)$ & $(0.462)$ & $(0.470)$ \\
\hline \multicolumn{5}{|l|}{ Number of } \\
\hline observations & & 14,401 & 848 & 13,553 \\
\hline
\end{tabular}

Notes: Standard deviations are in parentheses. ${ }^{*}, * *$, and $* * *$ indicate that the mean is statistically different between the sample with suicide thoughts and those without at the $10 \%, 5 \%$, and $1 \%$ levels, respectively. For each explanatory variable, we also created a dummy variable representing the missing observations.

${ }^{\mathrm{a}}$ Omitted category. 
Table 2A

OLS Estimates for Work-School Model: Suicide Thoughts

\begin{tabular}{|c|c|c|c|c|c|}
\hline \multirow[t]{3}{*}{ Variable } & Work- & Work- & Work- & Work- & Work- \\
\hline & School & School & School & School & School \\
\hline & (1) & (2) & (3) & (4) & (5) \\
\hline \multirow[t]{2}{*}{ Suicide thoughts } & $-0.048^{* * *}$ & $-0.038^{* * *}$ & $-0.033^{* *}$ & $-0.029^{* *}$ & $-0.029^{* *}$ \\
\hline & $(0.014)$ & $(0.014)$ & $(0.014)$ & $(0.014)$ & $(0.014)$ \\
\hline \multirow[t]{2}{*}{ Male } & $0.020^{\star * \star}$ & $0.019^{\star \star \star}$ & $0.014^{\star \star}$ & $0.013^{\star *}$ & $0.031^{\star * *}$ \\
\hline & $(0.006)$ & $(0.006)$ & $(0.006)$ & $(0.006)$ & $(0.006)$ \\
\hline \multirow[t]{2}{*}{ White } & 0.022 & 0.021 & 0.021 & 0.021 & $0.025^{\star}$ \\
\hline & $(0.013)$ & $(0.013)$ & $(0.013)$ & $(0.013)$ & $(0.013)$ \\
\hline \multirow[t]{2}{*}{ Black } & $-0.027^{\star}$ & -0.022 & -0.023 & -0.021 & -0.009 \\
\hline & $(0.015)$ & $(0.015)$ & $(0.015)$ & $(0.015)$ & $(0.015)$ \\
\hline \multirow[t]{2}{*}{ Hispanic } & 0.005 & 0.007 & 0.006 & 0.006 & 0.009 \\
\hline & $(0.011)$ & $(0.011)$ & $(0.011)$ & $(0.011)$ & $(0.011)$ \\
\hline \multirow[t]{2}{*}{ U.S. Born } & $-0.061^{* * *}$ & $-0.059^{\star * *}$ & $-0.057^{\star * *}$ & $-0.056^{\star \star *}$ & $-0.045^{\star * \star}$ \\
\hline & $(0.012)$ & $(0.012)$ & $(0.012)$ & $(0.012)$ & $(0.012)$ \\
\hline \multirow[t]{2}{*}{ Age19 } & 0.005 & 0.006 & 0.007 & 0.007 & 0.008 \\
\hline & $(0.033)$ & $(0.033)$ & $(0.033)$ & $(0.033)$ & $(0.033)$ \\
\hline \multirow[t]{2}{*}{ Age20 } & -0.005 & -0.004 & -0.000 & 0.001 & 0.010 \\
\hline & $(0.032)$ & $(0.032)$ & $(0.032)$ & $(0.032)$ & $(0.032)$ \\
\hline \multirow[t]{2}{*}{ Age21 } & -0.030 & -0.027 & -0.023 & -0.022 & -0.004 \\
\hline & $(0.033)$ & $(0.033)$ & $(0.033)$ & $(0.033)$ & $(0.033)$ \\
\hline
\end{tabular}




\begin{tabular}{|c|c|c|c|c|c|}
\hline Age22 & $\begin{array}{l}-0.043 \\
(0.033)\end{array}$ & $\begin{array}{l}-0.039 \\
(0.033)\end{array}$ & $\begin{array}{l}-0.034 \\
(0.033)\end{array}$ & $\begin{array}{l}-0.033 \\
(0.033)\end{array}$ & $\begin{array}{l}-0.009 \\
(0.033)\end{array}$ \\
\hline Age23 & $\begin{array}{l}-0.030 \\
(0.033)\end{array}$ & $\begin{array}{l}-0.027 \\
(0.033)\end{array}$ & $\begin{array}{l}-0.020 \\
(0.033)\end{array}$ & $\begin{array}{l}-0.020 \\
(0.033)\end{array}$ & $\begin{array}{l}0.004 \\
(0.033)\end{array}$ \\
\hline Age24 & $\begin{array}{l}-0.020 \\
(0.033)\end{array}$ & $\begin{array}{l}-0.019 \\
(0.033)\end{array}$ & $\begin{array}{l}-0.013 \\
(0.033)\end{array}$ & $\begin{array}{l}-0.012 \\
(0.034)\end{array}$ & $\begin{array}{l}0.013 \\
(0.033)\end{array}$ \\
\hline Age25 & $\begin{array}{l}-0.027 \\
(0.036)\end{array}$ & $\begin{array}{l}-0.026 \\
(0.036)\end{array}$ & $\begin{array}{l}-0.019 \\
(0.036)\end{array}$ & $\begin{array}{l}-0.019 \\
(0.036)\end{array}$ & $\begin{array}{l}0.015 \\
(0.036)\end{array}$ \\
\hline Age26+ & $\begin{array}{l}-0.027 \\
(0.049)\end{array}$ & $\begin{array}{l}-0.028 \\
(0.049)\end{array}$ & $\begin{array}{l}-0.018 \\
(0.049)\end{array}$ & $\begin{array}{l}-0.019 \\
(0.049)\end{array}$ & $\begin{array}{l}0.027 \\
(0.049)\end{array}$ \\
\hline PVT_w1B & $\begin{array}{l}0.067^{\star \star \star} \\
(0.010)\end{array}$ & $\begin{array}{l}0.067^{* \star \star} \\
(0.010)\end{array}$ & $\begin{array}{l}0.064^{* * *} \\
(0.010)\end{array}$ & $\begin{array}{l}0.063^{* * *} \\
(0.010)\end{array}$ & $\begin{array}{l}0.053^{* * *} \\
(0.010)\end{array}$ \\
\hline PVT_w1C & $\begin{array}{l}0.087^{* * *} \\
(0.010)\end{array}$ & $\begin{array}{l}0.087^{* \star *} \\
(0.010)\end{array}$ & $\begin{array}{l}0.081^{* * *} \\
(0.010)\end{array}$ & $\begin{array}{l}0.081^{* * *} \\
(0.010)\end{array}$ & $\begin{array}{l}0.062^{* * *} \\
(0.010)\end{array}$ \\
\hline PVT_w1D & $\begin{array}{l}0.113^{\star \star *} \\
(0.010)\end{array}$ & $\begin{array}{l}0.110^{\star * *} \\
(0.010)\end{array}$ & $\begin{array}{l}0.104^{\star * \star} \\
(0.010)\end{array}$ & $\begin{array}{l}0.104^{\star * *} \\
(0.010)\end{array}$ & $\begin{array}{l}0.076^{* * *} \\
(0.010)\end{array}$ \\
\hline Married & $\begin{array}{l}-0.046^{\star \star \star} \\
(0.009)\end{array}$ & $\begin{array}{l}-0.045^{\star \star *} \\
(0.009)\end{array}$ & $\begin{array}{l}-0.044^{\star \star \star} \\
(0.009)\end{array}$ & $\begin{array}{l}-0.045^{\star \star \star} \\
(0.009)\end{array}$ & $\begin{array}{l}-0.044^{\star \star *} \\
(0.009)\end{array}$ \\
\hline Mother high school & $\begin{array}{l}0.028^{* *} \\
(0.011)\end{array}$ & $\begin{array}{l}0.026^{* *} \\
(0.011)\end{array}$ & $\begin{array}{l}0.024^{* *} \\
(0.011)\end{array}$ & $\begin{array}{l}0.023^{* *} \\
(0.011)\end{array}$ & $\begin{array}{l}0.015 \\
(0.011)\end{array}$ \\
\hline Mother high school+ & $\begin{array}{l}0.065^{\star \star \star} \\
(0.011)\end{array}$ & $\begin{array}{l}0.061^{\star \star \star} \\
(0.011)\end{array}$ & $\begin{array}{l}0.059^{\star * *} \\
(0.011)\end{array}$ & $\begin{array}{l}0.058^{* * *} \\
(0.011)\end{array}$ & $\begin{array}{l}0.042^{* \star \star} \\
(0.011)\end{array}$ \\
\hline Non-wage2 & 0.018 & 0.016 & 0.017 & 0.016 & 0.019 \\
\hline
\end{tabular}




\begin{tabular}{|c|c|c|c|c|c|}
\hline & $(0.019)$ & $(0.019)$ & $(0.019)$ & $(0.019)$ & $(0.019)$ \\
\hline \multirow[t]{2}{*}{ Non-wage3 } & -0.011 & -0.013 & -0.011 & -0.012 & -0.011 \\
\hline & $(0.020)$ & $(0.020)$ & $(0.020)$ & $(0.020)$ & $(0.020)$ \\
\hline \multirow[t]{2}{*}{ Non-wage4 } & 0.012 & 0.009 & 0.010 & 0.010 & 0.009 \\
\hline & $(0.022)$ & $(0.022)$ & $(0.022)$ & $(0.022)$ & $(0.022)$ \\
\hline \multirow[t]{2}{*}{ Non-wage 5} & -0.034 & $-0.035^{\star}$ & -0.034 & $-0.035^{\star}$ & -0.034 \\
\hline & $(0.021)$ & $(0.021)$ & $(0.021)$ & $(0.021)$ & $(0.021)$ \\
\hline \multirow[t]{2}{*}{ Non-wage6 } & -0.026 & -0.028 & -0.027 & -0.028 & -0.027 \\
\hline & $(0.023)$ & $(0.023)$ & $(0.023)$ & $(0.023)$ & $(0.023)$ \\
\hline \multirow[t]{2}{*}{ Non-wage7 } & -0.002 & -0.006 & -0.005 & -0.005 & -0.003 \\
\hline & $(0.023)$ & $(0.022)$ & $(0.022)$ & $(0.022)$ & $(0.022)$ \\
\hline \multirow[t]{2}{*}{ Catholic } & -0.001 & -0.005 & -0.004 & -0.004 & -0.006 \\
\hline & $(0.011)$ & $(0.011)$ & $(0.011)$ & $(0.011)$ & $(0.011)$ \\
\hline \multirow[t]{2}{*}{ Protestant } & -0.002 & -0.003 & -0.003 & -0.003 & -0.006 \\
\hline & $(0.010)$ & $(0.010)$ & $(0.010)$ & $(0.010)$ & $(0.010)$ \\
\hline \multirow[t]{2}{*}{ No religion } & $-0.042^{* * *}$ & $-0.042^{* \star *}$ & $-0.040^{\star * *}$ & $-0.040^{\star * *}$ & $-0.033^{* * *}$ \\
\hline & $(0.011)$ & $(0.011)$ & $(0.011)$ & $(0.011)$ & $(0.011)$ \\
\hline \multirow[t]{2}{*}{ Healthy } & $0.104^{* * *}$ & $0.097^{* \star *}$ & $0.090^{* * *}$ & $0.087^{* * *}$ & $0.079^{* * *}$ \\
\hline & $(0.018)$ & $(0.018)$ & $(0.018)$ & $(0.018)$ & $(0.017)$ \\
\hline \multirow[t]{2}{*}{ Suicide attempt_w1 } & & -0.025 & 0.001 & 0.001 & 0.014 \\
\hline & & $(0.018)$ & $(0.018)$ & $(0.018)$ & $(0.018)$ \\
\hline \multirow[t]{2}{*}{ Suicide family } & & -0.014 & -0.011 & -0.011 & -0.012 \\
\hline & & $(0.020)$ & $(0.020)$ & $(0.020)$ & $(0.020)$ \\
\hline
\end{tabular}




\begin{tabular}{|c|c|c|c|c|}
\hline Suicide family_w1 & -0.023 & -0.015 & -0.015 & -0.010 \\
\hline & $(0.017)$ & $(0.017)$ & $(0.017)$ & $(0.017)$ \\
\hline Any abuse & -0.012 & -0.007 & -0.006 & -0.001 \\
\hline & $(0.008)$ & $(0.008)$ & $(0.008)$ & $(0.008)$ \\
\hline Foster & $-0.086^{\star * *}$ & $-0.075^{\star * *}$ & $-0.075^{\star \star *}$ & $-0.063^{\star *}$ \\
\hline & $(0.025)$ & $(0.025)$ & $(0.025)$ & $(0.025)$ \\
\hline Jailed father & $-0.035^{* * *}$ & $-0.034^{\star * *}$ & $-0.033^{* * *}$ & $-0.025^{\star \star}$ \\
\hline & $(0.010)$ & $(0.010)$ & $(0.010)$ & $(0.010)$ \\
\hline Depressed_w1 & & $-0.045^{\star * *}$ & $-0.042^{* \star *}$ & $-0.029^{\star * *}$ \\
\hline & & $(0.009)$ & $(0.009)$ & $(0.009)$ \\
\hline Counseling_w1 & & $-0.041^{* * *}$ & $-0.040^{* * *}$ & $-0.024^{\star *}$ \\
\hline & & $(0.011)$ & $(0.011)$ & $(0.011)$ \\
\hline Depressed_3 & & & $-0.023^{* * *}$ & $-0.019^{* *}$ \\
\hline & & & $(0.008)$ & $(0.008)$ \\
\hline Cocaine_w1 & & & & -0.034 \\
\hline & & & & $(0.022)$ \\
\hline Marijuana_w1 & & & & -0.001 \\
\hline & & & & $(0.008)$ \\
\hline Drug abuse & & & & -0.003 \\
\hline program_w1 & & & & $(0.021)$ \\
\hline Drunk_w1 & & & & 0.011 \\
\hline & & & & $(0.015)$ \\
\hline Alcohol at home_w1 & & & & $0.014^{\star *}$ \\
\hline
\end{tabular}


$(0.006)$

Drug at home_w1

$-0.007$

(0.019)

Volunteer work

$0.049^{\star \star \star}$

(0.006)

Ran away

$-0.024^{*}$

(0.013)

Repeat grade_w1

$-0.047^{* * *}$

(0.009)

School suspension_w1

$-0.044^{\star \star \star}$

(0.008)

Trouble with

-0.029 **

teachers_w1

(0.014)

Trouble with

$-0.032^{* *}$

students_w1

(0.014)

Felt close to people_w1

$-0.005$

(0.011)

Felt part of school_w1

0.002

(0.012)

Felt students

$-0.008$

prejudice_w1

$(0.007)$

Constant

$0.694^{* * *}$

$0.708^{\star * *}$

$0.721^{* * *}$

$0.749^{* \star *}$

$0.709^{\star * *}$

$(0.070) \quad(0.069)$

$(0.069) \quad(0.069)$

(0.069) 


$\begin{array}{llcccc}\text { State fixed effects } & \text { Yes } & \text { Yes } & \text { Yes } & \text { Yes } & \text { Yes } \\ \text { School fixed effects } & \text { Yes } & \text { Yes } & \text { Yes } & \text { Yes } & \text { Yes } \\ \text { R-squared } & 0.09 & 0.10 & 0.10 & 0.10 & 0.11 \\ \text { Observations } & 14,401 & 14,401 & 14,401 & 14,401 & 14,401\end{array}$

Notes: Robust standard errors are in parentheses. ${ }^{*},{ }^{*}$, and $* * *$ indicate statistical significance at the $10 \%, 5 \%$, and $1 \%$ levels, respectively. 


\section{Table 2B}

\section{OLS Estimates for Work-School Models: Suicide Attempts}

\begin{tabular}{|c|c|c|c|c|c|}
\hline \multirow[t]{3}{*}{ Variable } & Work- & Work- & Work- & Work- & Work- \\
\hline & School & School & School & School & School \\
\hline & (1) & (2) & (3) & (4) & (5) \\
\hline \multirow[t]{2}{*}{ Suicide attempt } & $-0.118^{\star * \star}$ & $-0.106^{\star \star \star}$ & $-0.101^{* * *}$ & $-0.095^{\star * *}$ & $-0.092^{\star * *}$ \\
\hline & $(0.030)$ & $(0.030)$ & $(0.030)$ & $(0.030)$ & $(0.030)$ \\
\hline \multirow[t]{2}{*}{ Male } & $0.020^{\star * *}$ & $0.019^{* * *}$ & $0.014^{\star *}$ & $0.013^{* *}$ & $0.031^{\star \star \star}$ \\
\hline & $(0.006)$ & $(0.006)$ & $(0.006)$ & $(0.006)$ & $(0.006)$ \\
\hline \multirow[t]{2}{*}{ White } & 0.021 & 0.020 & 0.020 & 0.021 & $0.025^{\star}$ \\
\hline & $(0.013)$ & $(0.013)$ & $(0.013)$ & $(0.013)$ & $(0.013)$ \\
\hline \multirow[t]{2}{*}{ Black } & $-0.026^{*}$ & -0.022 & -0.022 & -0.021 & -0.009 \\
\hline & $(0.015)$ & $(0.015)$ & $(0.015)$ & $(0.015)$ & $(0.015)$ \\
\hline \multirow[t]{2}{*}{ Hispanic } & 0.004 & 0.007 & 0.006 & 0.006 & 0.009 \\
\hline & $(0.011)$ & $(0.011)$ & $(0.011)$ & $(0.011)$ & $(0.011)$ \\
\hline \multirow[t]{2}{*}{ U.S. Born } & $-0.061^{\star * *}$ & $-0.059^{\star \star \star}$ & $-0.057^{* * *}$ & $-0.056^{\star \star \star}$ & $-0.046^{\star * *}$ \\
\hline & $(0.012)$ & $(0.012)$ & $(0.012)$ & $(0.012)$ & $(0.012)$ \\
\hline \multirow[t]{2}{*}{ Age19 } & 0.007 & 0.008 & 0.009 & 0.009 & 0.010 \\
\hline & $(0.033)$ & $(0.033)$ & $(0.033)$ & $(0.033)$ & $(0.033)$ \\
\hline \multirow[t]{2}{*}{ Age20 } & -0.004 & -0.003 & 0.001 & 0.002 & 0.012 \\
\hline & $(0.032)$ & $(0.032)$ & $(0.032)$ & $(0.032)$ & $(0.032)$ \\
\hline \multirow[t]{2}{*}{ Age21 } & -0.028 & -0.026 & -0.021 & -0.021 & -0.003 \\
\hline & $(0.033)$ & $(0.033)$ & $(0.033)$ & $(0.033)$ & $(0.033)$ \\
\hline
\end{tabular}




\begin{tabular}{|c|c|c|c|c|c|}
\hline Age22 & $\begin{array}{l}-0.041 \\
(0.033)\end{array}$ & $\begin{array}{l}-0.038 \\
(0.033)\end{array}$ & $\begin{array}{l}-0.033 \\
(0.033)\end{array}$ & $\begin{array}{l}-0.032 \\
(0.033)\end{array}$ & $\begin{array}{l}-0.008 \\
(0.033)\end{array}$ \\
\hline Age23 & $\begin{array}{l}-0.028 \\
(0.033)\end{array}$ & $\begin{array}{l}-0.025 \\
(0.033)\end{array}$ & $\begin{array}{l}-0.018 \\
(0.033)\end{array}$ & $\begin{array}{l}-0.018 \\
(0.033)\end{array}$ & $\begin{array}{l}0.005 \\
(0.033)\end{array}$ \\
\hline Age24 & $\begin{array}{l}-0.018 \\
(0.033)\end{array}$ & $\begin{array}{l}-0.017 \\
(0.033)\end{array}$ & $\begin{array}{l}-0.012 \\
(0.034)\end{array}$ & $\begin{array}{l}-0.012 \\
(0.034)\end{array}$ & $\begin{array}{l}0.014 \\
(0.033)\end{array}$ \\
\hline Age25 & $\begin{array}{l}-0.026 \\
(0.036)\end{array}$ & $\begin{array}{l}-0.025 \\
(0.036)\end{array}$ & $\begin{array}{l}-0.019 \\
(0.036)\end{array}$ & $\begin{array}{l}-0.018 \\
(0.036)\end{array}$ & $\begin{array}{l}0.016 \\
(0.036)\end{array}$ \\
\hline Age26+ & $\begin{array}{l}-0.025 \\
(0.049)\end{array}$ & $\begin{array}{l}-0.027 \\
(0.049)\end{array}$ & $\begin{array}{l}-0.017 \\
(0.049)\end{array}$ & $\begin{array}{l}-0.017 \\
(0.049)\end{array}$ & $\begin{array}{l}0.028 \\
(0.049)\end{array}$ \\
\hline PVT_w1B & $\begin{array}{l}0.067^{\star \star \star} \\
(0.010)\end{array}$ & $\begin{array}{l}0.067^{* \star \star} \\
(0.010)\end{array}$ & $\begin{array}{l}0.064^{* * *} \\
(0.010)\end{array}$ & $\begin{array}{l}0.063^{* * *} \\
(0.010)\end{array}$ & $\begin{array}{l}0.053^{* * *} \\
(0.010)\end{array}$ \\
\hline PVT_w1C & $\begin{array}{l}0.086^{\star * *} \\
(0.010)\end{array}$ & $\begin{array}{l}0.086^{\star * \star} \\
(0.010)\end{array}$ & $\begin{array}{l}0.081^{* * *} \\
(0.010)\end{array}$ & $\begin{array}{l}0.081^{* * *} \\
(0.010)\end{array}$ & $\begin{array}{l}0.062^{* * *} \\
(0.010)\end{array}$ \\
\hline PVT_w1D & $\begin{array}{l}0.112^{\star \star \star} \\
(0.010)\end{array}$ & $\begin{array}{l}0.110^{\star * *} \\
(0.010)\end{array}$ & $\begin{array}{l}0.103^{\star * \star} \\
(0.010)\end{array}$ & $\begin{array}{l}0.104^{\star * *} \\
(0.010)\end{array}$ & $\begin{array}{l}0.076^{* * *} \\
(0.010)\end{array}$ \\
\hline Married & $\begin{array}{l}-0.046^{\star \star \star} \\
(0.009)\end{array}$ & $\begin{array}{l}-0.044^{\star * *} \\
(0.009)\end{array}$ & $\begin{array}{l}-0.044^{\star \star \star} \\
(0.009)\end{array}$ & $\begin{array}{l}-0.044^{\star \star \star} \\
(0.009)\end{array}$ & $\begin{array}{l}-0.044^{\star \star *} \\
(0.009)\end{array}$ \\
\hline Mother high school & $\begin{array}{l}0.028^{* *} \\
(0.011)\end{array}$ & $\begin{array}{l}0.025^{\star *} \\
(0.011)\end{array}$ & $\begin{array}{l}0.023^{* *} \\
(0.011)\end{array}$ & $\begin{array}{l}0.023^{* *} \\
(0.011)\end{array}$ & $\begin{array}{l}0.015 \\
(0.011)\end{array}$ \\
\hline Mother high school+ & $\begin{array}{l}0.065^{\star \star \star} \\
(0.011)\end{array}$ & $\begin{array}{l}0.061^{\star * \star} \\
(0.011)\end{array}$ & $\begin{array}{l}0.058^{* \star *} \\
(0.011)\end{array}$ & $\begin{array}{l}0.058^{* * *} \\
(0.011)\end{array}$ & $\begin{array}{l}0.042^{* \star \star} \\
(0.011)\end{array}$ \\
\hline Non-wage2 & 0.018 & 0.016 & 0.016 & 0.015 & 0.018 \\
\hline
\end{tabular}




\begin{tabular}{|c|c|c|c|c|c|}
\hline & $(0.019)$ & $(0.019)$ & $(0.019)$ & $(0.019)$ & $(0.019)$ \\
\hline \multirow[t]{2}{*}{ Non-wage3 } & -0.011 & -0.013 & -0.012 & -0.012 & -0.011 \\
\hline & $(0.020)$ & $(0.020)$ & $(0.020)$ & $(0.020)$ & $(0.020)$ \\
\hline \multirow[t]{2}{*}{ Non-wage4 } & 0.011 & 0.008 & 0.010 & 0.010 & 0.009 \\
\hline & $(0.022)$ & $(0.022)$ & $(0.022)$ & $(0.022)$ & $(0.022)$ \\
\hline \multirow[t]{2}{*}{ Non-wage 5} & -0.034 & $-0.035^{\star}$ & -0.035 & $-0.035^{\star}$ & -0.034 \\
\hline & $(0.021)$ & $(0.021)$ & $(0.021)$ & $(0.021)$ & $(0.021)$ \\
\hline \multirow[t]{2}{*}{ Non-wage6 } & -0.027 & -0.029 & -0.027 & -0.028 & -0.028 \\
\hline & $(0.023)$ & $(0.023)$ & $(0.023)$ & $(0.023)$ & $(0.023)$ \\
\hline \multirow[t]{2}{*}{ Non-wage7 } & -0.003 & -0.006 & -0.005 & -0.006 & -0.004 \\
\hline & $(0.023)$ & $(0.022)$ & $(0.022)$ & $(0.022)$ & $(0.022)$ \\
\hline \multirow[t]{2}{*}{ Catholic } & -0.001 & -0.005 & -0.004 & -0.004 & -0.006 \\
\hline & $(0.011)$ & $(0.011)$ & $(0.011)$ & $(0.011)$ & $(0.011)$ \\
\hline \multirow[t]{2}{*}{ Protestant } & -0.002 & -0.004 & -0.003 & -0.003 & -0.006 \\
\hline & $(0.010)$ & $(0.010)$ & $(0.010)$ & $(0.010)$ & $(0.010)$ \\
\hline \multirow[t]{2}{*}{ No religion } & $-0.043^{* * *}$ & $-0.042^{* \star *}$ & $-0.040^{\star * *}$ & $-0.040^{\star * *}$ & $-0.033^{* * *}$ \\
\hline & $(0.011)$ & $(0.011)$ & $(0.011)$ & $(0.011)$ & $(0.011)$ \\
\hline \multirow[t]{2}{*}{ Healthy } & $0.104^{* * *}$ & $0.096^{* \star *}$ & $0.089^{* * *}$ & $0.087^{* * *}$ & $0.078^{* * *}$ \\
\hline & $(0.017)$ & $(0.017)$ & $(0.018)$ & $(0.018)$ & $(0.017)$ \\
\hline \multirow[t]{2}{*}{ Suicide attempt_w1 } & & -0.025 & 0.001 & 0.002 & 0.014 \\
\hline & & $(0.018)$ & $(0.018)$ & $(0.018)$ & $(0.018)$ \\
\hline \multirow[t]{2}{*}{ Suicide family } & & -0.015 & -0.011 & -0.011 & -0.012 \\
\hline & & $(0.020)$ & $(0.020)$ & $(0.020)$ & $(0.019)$ \\
\hline
\end{tabular}




\begin{tabular}{|c|c|c|c|c|}
\hline Suicide family_w1 & -0.022 & -0.014 & -0.014 & -0.009 \\
\hline & $(0.017)$ & $(0.017)$ & $(0.017)$ & $(0.017)$ \\
\hline Any abuse & -0.012 & -0.007 & -0.006 & -0.001 \\
\hline & $(0.008)$ & $(0.008)$ & $(0.008)$ & $(0.008)$ \\
\hline Foster & $-0.085^{\star \star \star}$ & $-0.074^{\star * *}$ & $-0.074^{\star * *}$ & $-0.062^{* *}$ \\
\hline & $(0.025)$ & $(0.025)$ & $(0.025)$ & $(0.025)$ \\
\hline Jailed father & $-0.035^{\star \star \star}$ & $-0.034^{\star * *}$ & $-0.034^{* * *}$ & $-0.025^{\star \star}$ \\
\hline & $(0.010)$ & $(0.010)$ & $(0.010)$ & $(0.010)$ \\
\hline Depressed_w1 & & $-0.045^{\star * *}$ & $-0.042^{* \star *}$ & $-0.029^{\star * *}$ \\
\hline & & $(0.009)$ & $(0.009)$ & $(0.009)$ \\
\hline Counseling_w1 & & $-0.041^{* * *}$ & $-0.040^{* * *}$ & $-0.024^{\star *}$ \\
\hline & & $(0.011)$ & $(0.011)$ & $(0.011)$ \\
\hline Depressed_w3 & & & $-0.022^{* * *}$ & $-0.019^{* *}$ \\
\hline & & & $(0.008)$ & $(0.008)$ \\
\hline Cocaine_w1 & & & & -0.034 \\
\hline & & & & $(0.022)$ \\
\hline Marijuana_w1 & & & & -0.001 \\
\hline & & & & $(0.008)$ \\
\hline Drug abuse & & & & -0.002 \\
\hline program_w1 & & & & $(0.021)$ \\
\hline Drunk_w1 & & & & 0.011 \\
\hline & & & & $(0.015)$ \\
\hline Alcohol at home_w1 & & & & $0.014^{\star *}$ \\
\hline
\end{tabular}


$(0.006)$

Drug at home_w1

$-0.007$

(0.019)

Volunteer work

$0.049^{\star \star \star}$

(0.006)

Ran away

$-0.024^{*}$

(0.013)

Repeat grade_w1

$-0.047^{* * *}$

(0.009)

School suspension_w1

$-0.044^{\star \star \star}$

(0.008)

Trouble with

-0.029 **

teachers_w1

$(0.014)$

Trouble with

$-0.031^{* *}$

students_w1

(0.014)

Felt close to people_w1

$-0.005$

(0.011)

Felt part of school_w1

0.001

(0.012)

Felt students

$-0.008$

prejudice_w1

$(0.007)$

Constant

$0.694^{* * *}$

$0.708^{\star * *}$

$0.722^{\star \star *}$

$0.750^{* \star *}$

$0.709^{\star * *}$

$(0.069) \quad(0.069)$

$(0.069) \quad(0.069)$

(0.069) 


$\begin{array}{llcccc}\text { State fixed effects } & \text { Yes } & \text { Yes } & \text { Yes } & \text { Yes } & \text { Yes } \\ \text { School fixed effects } & \text { Yes } & \text { Yes } & \text { Yes } & \text { Yes } & \text { Yes } \\ \text { R-squared } & 0.09 & 0.10 & 0.10 & 0.10 & 0.12 \\ \text { Observations } & 14,401 & 14,401 & 14,401 & 14,401 & 14,401\end{array}$

Notes: Robust standard errors are in parentheses. ${ }^{*},{ }^{*}$, and $* * *$ indicate statistical significance at the $10 \%, 5 \%$, and $1 \%$ levels, respectively. 


\section{Table 3}

Determinants of Suicide Thoughts and Attempts

\begin{tabular}{|c|c|c|}
\hline Variable & Suicide Thoughts & Suicide Attempts \\
\hline \multirow[t]{2}{*}{ Suicidal friend_w3 } & $0.115^{\star \star \star}$ & $0.033^{\star \star \star}$ \\
\hline & $(0.013)$ & $(0.007)$ \\
\hline \multirow[t]{2}{*}{ Suicidal friend_w1 } & 0.005 & 0.002 \\
\hline & $(0.006)$ & $(0.003)$ \\
\hline \multirow[t]{2}{*}{ Male } & 0.002 & -0.002 \\
\hline & (0.004) & (0.002) \\
\hline \multirow[t]{2}{*}{ White } & 0.007 & -0.001 \\
\hline & $(0.008)$ & $(0.004)$ \\
\hline \multirow[t]{2}{*}{ Black } & -0.007 & -0.001 \\
\hline & $(0.009)$ & $(0.005)$ \\
\hline \multirow[t]{2}{*}{ Hispanic } & -0.003 & -0.002 \\
\hline & $(0.007)$ & $(0.004)$ \\
\hline \multirow[t]{2}{*}{ U.S. Born } & $-0.016^{* *}$ & -0.007 \\
\hline & $(0.008)$ & $(0.004)$ \\
\hline \multirow[t]{2}{*}{ Age19 } & -0.004 & 0.017 \\
\hline & $(0.024)$ & $(0.011)$ \\
\hline \multirow[t]{2}{*}{ Age20 } & -0.022 & 0.005 \\
\hline & $(0.024)$ & $(0.011)$ \\
\hline \multirow[t]{2}{*}{ Age21 } & -0.028 & 0.004 \\
\hline & $(0.024)$ & $(0.011)$ \\
\hline
\end{tabular}




\begin{tabular}{|c|c|c|}
\hline \multirow[t]{2}{*}{ Age22 } & -0.028 & 0.003 \\
\hline & $(0.024)$ & $(0.011)$ \\
\hline \multirow[t]{2}{*}{ Age23 } & $-0.043^{*}$ & 0.001 \\
\hline & $(0.024)$ & $(0.011)$ \\
\hline \multirow[t]{2}{*}{ Age24 } & -0.027 & 0.001 \\
\hline & $(0.024)$ & $(0.011)$ \\
\hline \multirow[t]{2}{*}{ Age25 } & -0.018 & 0.000 \\
\hline & $(0.025)$ & $(0.011)$ \\
\hline \multirow[t]{2}{*}{ Age26+ } & $-0.051^{*}$ & -0.003 \\
\hline & $(0.028)$ & $(0.014)$ \\
\hline \multirow[t]{2}{*}{ PVT_w1B } & $0.017^{* * *}$ & $0.006^{*}$ \\
\hline & $(0.005)$ & $(0.003)$ \\
\hline \multirow[t]{2}{*}{ PVT_w1C } & $0.020^{* * *}$ & 0.004 \\
\hline & $(0.006)$ & $(0.003)$ \\
\hline \multirow[t]{2}{*}{ PVT_w1D } & $0.030^{* * *}$ & 0.003 \\
\hline & $(0.006)$ & $(0.003)$ \\
\hline \multirow[t]{2}{*}{ Married } & $-0.027^{\star \star \star}$ & $-0.007^{* * *}$ \\
\hline & $(0.005)$ & $(0.002)$ \\
\hline \multirow[t]{2}{*}{ Mother high school } & 0.006 & -0.005 \\
\hline & $(0.006)$ & $(0.004)$ \\
\hline \multirow[t]{2}{*}{ Mother high school+ } & 0.005 & -0.005 \\
\hline & $(0.006)$ & $(0.004)$ \\
\hline Non-wage2 & -0.009 & -0.008 \\
\hline
\end{tabular}




\begin{tabular}{|c|c|c|}
\hline & $(0.013)$ & $(0.008)$ \\
\hline \multirow[t]{2}{*}{ Non-wage3 } & -0.013 & -0.006 \\
\hline & $(0.013)$ & $(0.008)$ \\
\hline \multirow[t]{2}{*}{ Non-wage4 } & -0.012 & -0.006 \\
\hline & $(0.015)$ & $(0.009)$ \\
\hline \multirow[t]{2}{*}{ Non-wage 5} & -0.012 & -0.008 \\
\hline & $(0.014)$ & $(0.009)$ \\
\hline \multirow[t]{2}{*}{ Non-wage6 } & -0.002 & -0.006 \\
\hline & $(0.015)$ & $(0.009)$ \\
\hline \multirow[t]{2}{*}{ Non-wage 7} & -0.015 & -0.012 \\
\hline & $(0.015)$ & $(0.009)$ \\
\hline \multirow[t]{2}{*}{ Catholic } & -0.005 & -0.003 \\
\hline & $(0.007)$ & $(0.004)$ \\
\hline \multirow[t]{2}{*}{ Protestant } & -0.005 & -0.005 \\
\hline & $(0.006)$ & $(0.004)$ \\
\hline \multirow[t]{2}{*}{ No religion } & 0.012 & 0.001 \\
\hline & $(0.007)$ & $(0.004)$ \\
\hline \multirow[t]{2}{*}{ Healthy } & $-0.061^{* * *}$ & $-0.026^{* * *}$ \\
\hline & $(0.014)$ & $(0.009)$ \\
\hline \multirow[t]{2}{*}{ Suicide attempt_w1 } & $0.080^{\star \star *}$ & $0.035^{\star * *}$ \\
\hline & $(0.016)$ & $(0.010)$ \\
\hline \multirow[t]{2}{*}{ Suicide family_w3 } & $0.089^{\star \star *}$ & $0.029 * *$ \\
\hline & $(0.018)$ & $(0.011)$ \\
\hline
\end{tabular}




\begin{tabular}{|c|c|c|}
\hline Suicide family_w1 & -0.002 & 0.011 \\
\hline & $(0.011)$ & $(0.007)$ \\
\hline Any abuse & $0.037^{\star \star \star}$ & $0.010^{\star \star \star}$ \\
\hline & $(0.006)$ & $(0.003)$ \\
\hline Foster & 0.010 & 0.015 \\
\hline & $(0.016)$ & $(0.011)$ \\
\hline Jailed father & $0.024^{\star \star \star}$ & 0.004 \\
\hline & $(0.007)$ & $(0.004)$ \\
\hline Depressed_w1 & $0.017^{\star \star \star}$ & 0.003 \\
\hline & $(0.006)$ & $(0.003)$ \\
\hline Counseling_w1 & $0.017^{* *}$ & 0.005 \\
\hline & $(0.008)$ & $(0.004)$ \\
\hline Depressed_w3 & $0.065^{\star \star \star}$ & $0.022^{\star * \star}$ \\
\hline & $(0.006)$ & $(0.003)$ \\
\hline Constant & 0.025 & 0.016 \\
\hline & $(0.048)$ & $(0.028)$ \\
\hline State fixed effects & Yes & Yes \\
\hline School fixed effects & Yes & Yes \\
\hline R-squared & 0.09 & 0.05 \\
\hline Observations & 14,401 & 14,401 \\
\hline
\end{tabular}

Notes: Robust standard errors are in parentheses. ${ }^{*}, * *$, and $* * *$ indicate statistical significance at the $10 \%, 5 \%$, and $1 \%$ levels, respectively. 


\section{Table 4}

TSLS Estimates for Work-School Model

\begin{tabular}{|c|c|c|}
\hline Variable & Work-School & Work-School \\
\hline Suicide thoughts & $\begin{array}{l}-0.214^{*} \\
(0.113)\end{array}$ & \\
\hline Suicide attempt & & $\begin{array}{l}-0.736^{\star} \\
(0.407)\end{array}$ \\
\hline State fixed effects & Yes & Yes \\
\hline School fixed effects & Yes & Yes \\
\hline R-squared & 0.09 & 0.06 \\
\hline Observations & 14,401 & 14,401 \\
\hline F-test on instruments & $42.46^{\star \star \star}$ & $10.87^{* * *}$ \\
\hline Durbin-Wu-Hausman test statistic & 0.64 & 0.39 \\
\hline Hansen J Statistic - Overidentification & 0.15 & 0.20 \\
\hline
\end{tabular}

Notes: Robust standard errors are in parentheses. $*, * *$, and $* * *$ indicate statistical significance at the $10 \%, 5 \%$, and $1 \%$ levels, respectively. Instruments are indicators of whether the respondent reports having friends who attempted suicide in Wave 1 and in Wave 3. 


\section{Table 5}

\section{Fixed Effects Estimates for Work-School Model from the Sibling and Twin Samples}

\begin{tabular}{lllll}
\hline \multicolumn{2}{l}{ Sibling Fixed Effects } & \multicolumn{2}{l}{ Twin Fixed Effects } \\
\cline { 2 - 4 } Variable & Work-School & Work-School & Work-School & Work-School \\
\hline Suicide thoughts & $-0.085^{*}$ & & $-0.190^{* *}$ & \\
& $(0.052)$ & & $(0.076)$ & $-0.310^{*}$ \\
Suicide attempt & & -0.088 & & $(0.168)$ \\
& & $(0.095)$ & & 0.09 \\
R-squared & 0.16 & 0.16 & 0.09 & 760 \\
Observations & 2,134 & 2,134 & 760 & \\
\hline
\end{tabular}

Notes: Robust standard errors are in parentheses. *, **, and *** indicate statistical significance at the $10 \%, 5 \%$, and $1 \%$ levels, respectively. The models with sibling fixed effects also include school fixed effects. There was little variation to warrant including state fixed effects for both sibling and twin fixed effects models. The twin fixed effects model did include neither the state nor the school fixed effects due to little variation. 


\section{Table 6}

Multinomial Logit Coefficients for the Work-School Model

\begin{tabular}{|c|c|c|c|c|c|c|}
\hline \multirow[b]{2}{*}{ Variable } & \multicolumn{3}{|c|}{ No } & \multicolumn{3}{|c|}{ No } \\
\hline & $\begin{array}{l}\text { School, } \\
\text { No Work }\end{array}$ & $\begin{array}{l}\text { School, } \\
\text { Work }\end{array}$ & $\begin{array}{l}\text { School } \\
\text { Work }\end{array}$ & $\begin{array}{l}\text { School, } \\
\text { No Work }\end{array}$ & $\begin{array}{l}\text { School, } \\
\text { Work }\end{array}$ & $\begin{array}{l}\text { School, } \\
\text { Work }\end{array}$ \\
\hline Suicide thoughts & $\begin{array}{l}-0.285^{\star \star} \\
(0.139)\end{array}$ & $\begin{array}{l}-0.188^{*} \\
(0.103)\end{array}$ & $\begin{array}{l}-0.228^{*} \\
(0.119)\end{array}$ & --- & --- & --- \\
\hline Suicide attempt & --- & --- & --- & $\begin{array}{l}-0.492^{\star \star} \\
(0.239)\end{array}$ & $\begin{array}{l}-0.568^{* * *} \\
(0.176)\end{array}$ & $\begin{array}{l}-0.707^{* * *} \\
(0.214)\end{array}$ \\
\hline Male & $\begin{array}{l}-0.151^{\star *} \\
(0.066)\end{array}$ & $\begin{array}{l}0.269^{* * *} \\
(0.051)\end{array}$ & $\begin{array}{l}-0.237^{\star * \star} \\
(0.058)\end{array}$ & $\begin{array}{l}-0.152^{\star \star} \\
(0.066)\end{array}$ & $\begin{array}{l}0.267^{* * *} \\
(0.051)\end{array}$ & $\begin{array}{l}-0.239^{* * *} \\
(0.058)\end{array}$ \\
\hline White & $\begin{array}{l}-0.183^{*} \\
(0.109)\end{array}$ & $\begin{array}{l}0.376^{\star * *} \\
(0.086)\end{array}$ & $\begin{array}{l}0.291^{* * *} \\
(0.099)\end{array}$ & $\begin{array}{l}-0.188^{*} \\
(0.109)\end{array}$ & $\begin{array}{l}0.372^{\star \star \star} \\
(0.086)\end{array}$ & $\begin{array}{l}0.285^{\star \star \star} \\
(0.099)\end{array}$ \\
\hline Black & $\begin{array}{l}-0.194 \\
(0.122)\end{array}$ & $\begin{array}{l}-0.179^{*} \\
(0.096)\end{array}$ & $\begin{array}{l}0.031 \\
(0.112)\end{array}$ & $\begin{array}{l}-0.194 \\
(0.122)\end{array}$ & $\begin{array}{l}-0.181^{*} \\
(0.096)\end{array}$ & $\begin{array}{l}0.028 \\
(0.112)\end{array}$ \\
\hline Hispanic & $\begin{array}{l}-0.128 \\
(0.111)\end{array}$ & $\begin{array}{l}-0.048 \\
(0.076)\end{array}$ & $\begin{array}{l}0.283^{\star \star \star} \\
(0.087)\end{array}$ & $\begin{array}{l}-0.128 \\
(0.111)\end{array}$ & $\begin{array}{l}-0.049 \\
(0.076)\end{array}$ & $\begin{array}{l}0.282^{\star \star \star} \\
(0.087)\end{array}$ \\
\hline U.S. Born & $\begin{array}{l}-0.720^{\star \star \star} \\
(0.141)\end{array}$ & $\begin{array}{l}-0.271^{* *} \\
(0.108)\end{array}$ & $\begin{array}{l}-1.001^{* * *} \\
(0.120)\end{array}$ & $\begin{array}{l}-0.723^{\star \star \star} \\
(0.141)\end{array}$ & $\begin{array}{l}-0.275^{\star *} \\
(0.108)\end{array}$ & $\begin{array}{l}-1.005^{\star \star \star} \\
(0.120)\end{array}$ \\
\hline Age19 & $\begin{array}{l}-0.209 \\
(0.288)\end{array}$ & $\begin{array}{l}0.504 \\
(0.314)\end{array}$ & $\begin{array}{l}-0.012 \\
(0.279)\end{array}$ & $\begin{array}{l}-0.198 \\
(0.289)\end{array}$ & $\begin{array}{l}0.514 \\
(0.315)\end{array}$ & $\begin{array}{l}0.002 \\
(0.281)\end{array}$ \\
\hline Age20 & $\begin{array}{l}-0.466 \\
(0.284)\end{array}$ & $\begin{array}{l}0.745^{\star \star} \\
(0.308)\end{array}$ & $\begin{array}{l}-0.142 \\
(0.275)\end{array}$ & $\begin{array}{l}-0.460 \\
(0.285)\end{array}$ & $\begin{array}{l}0.749^{* *} \\
(0.310)\end{array}$ & $\begin{array}{l}-0.135 \\
(0.277)\end{array}$ \\
\hline
\end{tabular}




\begin{tabular}{|c|c|c|c|c|c|c|}
\hline Age21 & $\begin{array}{l}-0.687^{\star *} \\
(0.283)\end{array}$ & $\begin{array}{l}0.795^{\star \star *} \\
(0.306)\end{array}$ & $\begin{array}{l}-0.250 \\
(0.273)\end{array}$ & $\begin{array}{l}-0.678^{\star *} \\
(0.284)\end{array}$ & $\begin{array}{l}0.801^{* * *} \\
(0.308)\end{array}$ & $\begin{array}{l}-0.242 \\
(0.275)\end{array}$ \\
\hline Age22 & $\begin{array}{l}-1.213^{\star * *} \\
(0.285)\end{array}$ & $\begin{array}{l}1.024^{\star * *} \\
(0.305)\end{array}$ & $\begin{array}{l}-0.493^{*} \\
(0.274)\end{array}$ & $\begin{array}{l}-1.206^{\star * *} \\
(0.285)\end{array}$ & $\begin{array}{l}1.027^{\star \star \star} \\
(0.307)\end{array}$ & $\begin{array}{l}-0.487^{*} \\
(0.275)\end{array}$ \\
\hline Age23 & $\begin{array}{l}-1.441^{* * *} \\
(0.287)\end{array}$ & $\begin{array}{l}1.232^{* \star *} \\
(0.305)\end{array}$ & $\begin{array}{l}-0.563^{* *} \\
(0.275)\end{array}$ & $\begin{array}{l}-1.431^{\star * *} \\
(0.288)\end{array}$ & $\begin{array}{l}1.237^{\star \star \star} \\
(0.307)\end{array}$ & $\begin{array}{l}-0.555^{\star \star} \\
(0.276)\end{array}$ \\
\hline Age24 & $\begin{array}{l}-1.584^{* * *} \\
(0.292)\end{array}$ & $\begin{array}{l}1.372^{\star \star *} \\
(0.307)\end{array}$ & $\begin{array}{l}-0.759^{* * *} \\
(0.278)\end{array}$ & $\begin{array}{l}-1.578^{\star * *} \\
(0.293)\end{array}$ & $\begin{array}{l}1.374^{* * *} \\
(0.308)\end{array}$ & $\begin{array}{l}-0.755^{\star \star \star} \\
(0.280)\end{array}$ \\
\hline Age25 & $\begin{array}{l}-1.633^{\star \star \star} \\
(0.332)\end{array}$ & $\begin{array}{l}1.277^{\star \star *} \\
(0.317)\end{array}$ & $\begin{array}{l}-0.892^{\star \star \star} \\
(0.301)\end{array}$ & $\begin{array}{l}-1.630^{\star \star \star} \\
(0.332)\end{array}$ & $\begin{array}{l}1.276^{\star \star \star} \\
(0.318)\end{array}$ & $\begin{array}{l}-0.891^{\star * \star} \\
(0.303)\end{array}$ \\
\hline Age26+ & $\begin{array}{l}-1.551^{\star \star \star} \\
(0.520)\end{array}$ & $\begin{array}{l}1.163^{\star * *} \\
(0.370)\end{array}$ & $\begin{array}{l}-0.971^{* *} \\
(0.426)\end{array}$ & $\begin{array}{l}-1.539^{\star \star \star} \\
(0.521)\end{array}$ & $\begin{array}{l}1.168^{\star \star \star} \\
(0.372)\end{array}$ & $\begin{array}{l}-0.962^{\star \star} \\
(0.427)\end{array}$ \\
\hline PVT_w1B & $\begin{array}{l}0.402^{\star * *} \\
(0.097)\end{array}$ & $\begin{array}{l}0.423^{* * *} \\
(0.067)\end{array}$ & $\begin{array}{l}0.538^{\star * *} \\
(0.082)\end{array}$ & $\begin{array}{l}0.401^{\star * *} \\
(0.097)\end{array}$ & $\begin{array}{l}0.424^{\star * *} \\
(0.067)\end{array}$ & $\begin{array}{l}0.539^{\star * *} \\
(0.082)\end{array}$ \\
\hline PVT_w1C & $\begin{array}{l}0.742^{* \star \star} \\
(0.103)\end{array}$ & $\begin{array}{l}0.508^{* * *} \\
(0.076)\end{array}$ & $\begin{array}{l}1.001^{\star * \star} \\
(0.089)\end{array}$ & $\begin{array}{l}0.740^{\star \star *} \\
(0.103)\end{array}$ & $\begin{array}{l}0.509^{* * *} \\
(0.076)\end{array}$ & $\begin{array}{l}1.002^{* \star \star} \\
(0.089)\end{array}$ \\
\hline PVT_w1D & $\begin{array}{l}1.385^{\star \star \star} \\
(0.107)\end{array}$ & $\begin{array}{l}0.724^{\star \star *} \\
(0.084)\end{array}$ & $\begin{array}{l}1.470^{\star * \star} \\
(0.094)\end{array}$ & $\begin{array}{l}1.378^{\star \star \star} \\
(0.107)\end{array}$ & $\begin{array}{l}0.720^{* * *} \\
(0.084)\end{array}$ & $\begin{array}{l}1.467^{\star \star \star} \\
(0.094)\end{array}$ \\
\hline Married & $\begin{array}{l}-0.836^{\star \star \star} \\
(0.104)\end{array}$ & $\begin{array}{l}-0.156^{\star \star} \\
(0.062)\end{array}$ & $\begin{array}{l}-0.910^{* * *} \\
(0.084)\end{array}$ & $\begin{array}{l}-0.833^{\star \star \star} \\
(0.104)\end{array}$ & $\begin{array}{l}-0.156^{\star *} \\
(0.062)\end{array}$ & $\begin{array}{l}-0.910^{\star * *} \\
(0.084)\end{array}$ \\
\hline Mother high school & $\begin{array}{l}0.428^{\star * *} \\
(0.119)\end{array}$ & $\begin{array}{l}0.132^{\star} \\
(0.075)\end{array}$ & $\begin{array}{l}0.311^{\star * *} \\
(0.091)\end{array}$ & $\begin{array}{l}0.425^{\star \star \star} \\
(0.119)\end{array}$ & $\begin{array}{l}0.127^{\star} \\
(0.075)\end{array}$ & $\begin{array}{l}0.305^{\star * *} \\
(0.091)\end{array}$ \\
\hline Mother high school+ & $1.216^{\star \star \star}$ & $0.248^{\star \star *}$ & $0.847^{\star * \star}$ & $1.212^{\star \star \star}$ & $0.245^{\star \star \star}$ & $0.842^{\star * *}$ \\
\hline
\end{tabular}




\begin{tabular}{|c|c|c|c|c|c|c|}
\hline & $(0.116)$ & $(0.077)$ & $(0.091)$ & $(0.116)$ & $(0.077)$ & $(0.091)$ \\
\hline \multirow[t]{2}{*}{ Non-wage2 } & -0.056 & 0.146 & -0.067 & -0.056 & 0.143 & -0.070 \\
\hline & $(0.200)$ & $(0.145)$ & $(0.166)$ & $(0.200)$ & $(0.145)$ & $(0.166)$ \\
\hline \multirow[t]{2}{*}{ Non-wage3 } & 0.086 & -0.196 & -0.013 & 0.087 & -0.197 & -0.013 \\
\hline & $(0.210)$ & $(0.155)$ & $(0.176)$ & $(0.210)$ & $(0.156)$ & $(0.176)$ \\
\hline \multirow[t]{2}{*}{ Non-wage4 } & $0.448^{*}$ & -0.112 & 0.176 & $0.450^{*}$ & -0.112 & 0.175 \\
\hline & $(0.231)$ & $(0.177)$ & $(0.197)$ & $(0.231)$ & $(0.178)$ & $(0.197)$ \\
\hline \multirow[t]{2}{*}{ Non-wage5 } & 0.133 & $-0.376^{\star *}$ & $-0.309^{*}$ & 0.133 & $-0.378^{\star \star}$ & $-0.311^{*}$ \\
\hline & $(0.215)$ & $(0.161)$ & $(0.183)$ & $(0.215)$ & $(0.161)$ & $(0.184)$ \\
\hline \multirow[t]{2}{*}{ Non-wage6 } & 0.259 & $-0.398^{* *}$ & -0.206 & 0.255 & $-0.403^{\star *}$ & -0.211 \\
\hline & $(0.232)$ & $(0.176)$ & $(0.199)$ & $(0.232)$ & $(0.177)$ & $(0.199)$ \\
\hline \multirow[t]{2}{*}{ Non-wage7 } & $0.431^{*}$ & -0.150 & -0.151 & $0.428^{*}$ & -0.157 & -0.158 \\
\hline & $(0.235)$ & $(0.180)$ & $(0.205)$ & $(0.235)$ & $(0.180)$ & $(0.205)$ \\
\hline \multirow[t]{2}{*}{ Catholic } & -0.024 & 0.055 & 0.149 & -0.025 & 0.054 & 0.148 \\
\hline & $(0.114)$ & $(0.090)$ & $(0.101)$ & $(0.114)$ & $(0.090)$ & $(0.101)$ \\
\hline \multirow[t]{2}{*}{ Protestant } & -0.005 & 0.003 & -0.026 & -0.007 & 0.001 & -0.030 \\
\hline & $(0.100)$ & $(0.080)$ & $(0.090)$ & $(0.100)$ & $(0.080)$ & $(0.090)$ \\
\hline \multirow[t]{2}{*}{ No religion } & $-0.505^{\star * *}$ & $-0.179^{* *}$ & $-0.449^{* \star *}$ & $-0.510^{* * *}$ & $-0.182^{* *}$ & $-0.452^{* * *}$ \\
\hline & $(0.114)$ & $(0.087)$ & $(0.100)$ & $(0.114)$ & $(0.088)$ & $(0.100)$ \\
\hline \multirow[t]{2}{*}{ Healthy } & $0.564^{\star * *}$ & $0.462^{* * *}$ & $0.802^{* * *}$ & $0.568^{* * *}$ & $0.458^{* * *}$ & $0.796^{* * *}$ \\
\hline & $(0.155)$ & $(0.101)$ & $(0.135)$ & $(0.155)$ & $(0.101)$ & $(0.134)$ \\
\hline \multirow[t]{2}{*}{ Suicide attempt_w1 } & -0.013 & 0.078 & -0.144 & -0.014 & 0.084 & -0.135 \\
\hline & $(0.182)$ & $(0.124)$ & $(0.152)$ & $(0.182)$ & $(0.124)$ & $(0.152)$ \\
\hline
\end{tabular}




\begin{tabular}{|c|c|c|c|c|c|c|}
\hline Suicide family_w3 & -0.075 & -0.053 & -0.143 & -0.090 & -0.054 & -0.146 \\
\hline & $(0.195)$ & $(0.138)$ & $(0.166)$ & $(0.193)$ & $(0.136)$ & $(0.165)$ \\
\hline Suicide family_w1 & -0.190 & -0.077 & -0.139 & -0.183 & -0.068 & -0.129 \\
\hline & $(0.165)$ & $(0.112)$ & $(0.136)$ & $(0.165)$ & $(0.112)$ & $(0.136)$ \\
\hline Any abuse & $-0.189^{* *}$ & 0.002 & -0.088 & $-0.194^{* *}$ & 0.002 & -0.088 \\
\hline & $(0.083)$ & $(0.060)$ & $(0.070)$ & $(0.083)$ & $(0.060)$ & $(0.070)$ \\
\hline Foster & $-0.664^{\star \star *}$ & $-0.392^{\star \star \star}$ & $-0.625^{\star \star \star}$ & $-0.659^{* \star *}$ & $-0.386^{\star \star *}$ & $-0.616^{\star * *}$ \\
\hline & $(0.242)$ & $(0.140)$ & $(0.192)$ & $(0.242)$ & $(0.140)$ & $(0.192)$ \\
\hline Jailed father & $-0.527^{\star \star \star}$ & $-0.124^{\star}$ & $-0.357^{\star * \star}$ & $-0.531^{* * *}$ & $-0.127^{*}$ & $-0.361^{* * *}$ \\
\hline & $(0.102)$ & $(0.069)$ & $(0.083)$ & $(0.102)$ & $(0.069)$ & $(0.083)$ \\
\hline Depressed_w1 & $-0.356^{\star * \star}$ & $-0.184^{\star \star *}$ & $-0.417^{\star \star \star}$ & $-0.359^{* * *}$ & $-0.185^{\star * *}$ & $-0.418^{* * *}$ \\
\hline & $(0.087)$ & $(0.060)$ & $(0.073)$ & $(0.087)$ & $(0.060)$ & $(0.073)$ \\
\hline Counseling_w1 & $-0.519^{\star \star \star}$ & $-0.228^{\star \star \star}$ & $-0.303^{\star \star \star}$ & $-0.521^{* \star *}$ & $-0.229^{\star \star *}$ & $-0.303^{* \star *}$ \\
\hline & $(0.108)$ & $(0.075)$ & $(0.087)$ & $(0.108)$ & $(0.075)$ & $(0.087)$ \\
\hline Depressed_w3 & $-0.167^{\star *}$ & $-0.189^{* * *}$ & $-0.131^{*}$ & $-0.173^{\star *}$ & $-0.187^{* * *}$ & $-0.128^{*}$ \\
\hline & $(0.079)$ & $(0.059)$ & $(0.068)$ & $(0.078)$ & $(0.059)$ & $(0.067)$ \\
\hline Constant & 0.373 & $-0.712^{*}$ & 0.255 & 0.372 & $-0.698^{*}$ & 0.269 \\
\hline & $(0.410)$ & $(0.372)$ & $(0.371)$ & $(0.410)$ & $(0.373)$ & $(0.372)$ \\
\hline Observations & 14,392 & 14,392 & 14,392 & 14,392 & 14,392 & 14,392 \\
\hline
\end{tabular}

Notes: Omitted outcome in the multinomial logit model is No-school/No-work. Robust standard errors are in parentheses. ${ }^{*}, *$, and $* * *$ indicate statistical significance at the $10 \%, 5 \%$, and $1 \%$ levels, respectively. 